\title{
Phytotoxic Potential and Phenolic Profile of Extracts from Scrophularia striata
}

\author{
Seyyed Sasan Mousavi ${ }^{1}$, Akbar Karami ${ }^{1, *(\mathbb{D}}$, Tahereh Movahhed Haghighi ${ }^{1}$, Saeed Alizadeh ${ }^{2}$ \\ and Filippo Maggi ${ }^{3, *(1)}$
}

1 Department of Horticultural Science, School of Agriculture, Shiraz University, Shiraz 71441-65186, Iran; seyedsasanmousavi66@gmail.com (S.S.M.); tmovahhed@gmail.com (T.M.H.)

2 Department of Natural Resources and Environment Engineering, School of Agriculture, Shiraz University, Shiraz 71441-65186, Iran; saeedalizadehshz@gmail.com

3 School of Pharmacy, University of Camerino, 62032 Camerino, Italy

* Correspondence: akarami2004@gmail.com (A.K.); filippo.maggi@unicam.it (F.M.); Tel.: +39-0737-404506 (F.M.)

check for updates

Citation: Mousavi, S.S.; Karami, A.; Haghighi, T.M.; Alizadeh, S.; Maggi, F. Phytotoxic Potential and Phenolic Profile of Extracts from Scrophularia striata. Plants 2021, 10, 135. https:// doi.org/10.3390/plants10010135

Received: 20 December 2020 Accepted: 8 January 2021

Published: 11 January 2021

Publisher's Note: MDPI stays neutral with regard to jurisdictional clai$\mathrm{ms}$ in published maps and institutional affiliations.

Copyright: $(\odot 2021$ by the authors. Licensee MDPI, Basel, Switzerland. This article is an open access article distributed under the terms and conditions of the Creative Commons Attribution (CC BY) license (https:// creativecommons.org/licenses/by/ $4.0 /)$.

\begin{abstract}
A large number of plants produce secondary metabolites known as allelochemicals that are capable of inhibiting the germination of competitive species. This process is known as allelopathy and is mediated by several classes of chemicals, among which phenolic compounds are the most frequent. Thus, plant allelochemicals can be used to control weeds in agricultural systems. In the present work, we analyzed the phenolic profile and phytotoxic potential of different extracts (pure water or water: ethanol 50:50) from Scrophularia striata plants that were collected from two ecological regions in Iran (Pahleh and Lizan). The total polyphenolic content (TPC), as evaluated by the Folin-Ciocolteau method, ranged from $28.3 \mathrm{mg} / \mathrm{g}$ in the aqueous extract obtained from the Lizan ecotype to $39.6 \mathrm{mg} / \mathrm{g}$ in the hydroalcoholic extract obtained from the Pahleh ecotype. Moreover, HPLC analysis was aimed at determining the content of eight phenolic compounds, namely eugenol, rosmarinic acid, hesperetin, hesperedin, trans-ferulic acid, vanillin, and caffeic acid. According to the results, rosmarinic acid appeared to be the most abundant component. The phytotoxic activities of $S$. striata extracts were examined on the seed germination of a crop species, Lepidium sativum, and two weeds, Chenopodium album and Malva sylvestris. All extracts showed inhibitory effects on these species. The efficiency of these inhibitory effects depended on the type of plant species, origin, and concentration of extract. The highest phytotoxic activity was caused by approximately $1 \%$ concentration of extract. The most susceptible weed was M. sylvestris. The extracts that were obtained from the Pahleh ecotype, notably the hydroalcoholic ones, showed higher phytotoxicity against L. sativum, C. album and M. sylvestris. These results encourage further studies to support the use of $S$. striata as a source of bioherbicides.
\end{abstract}

Keywords: Scrophularia striata; allelochemicals; germination; ecotype; phenolic profile

\section{Introduction}

Scrophularia striata Boiss., known as "Tashaneh Dari" [1], belongs to the Scrophulariaceae family and grows widely in several regions throughout the world. Its main center of distribution is Iran [2]. Scrophulariaceae is a large angiosperm family, widely distributed in central Asia, Europe, and North America. It comprises about 3000 species and 220 genera [3,4]. The distribution of $S$. striata occurs predominantly in the arid and semi-arid regions of southwestern Iran [5]. Alkaloids, phenolics, iridoids, and cryptophilic acids are active constituents that accumulate in different parts of S. striata [6-8]. In the Iranian folk medicine, this species has been used as a wound healing agent [9].

Weeds are a significant threat to crop productivity in agroecosystems since the beginning of agriculture on earth, and the lack of weed control is a pressing concern among farmers [10]. Thus, herbicides have been mostly effective in controlling weeds [11]. Nonetheless, there is a growing concern among the public scientific community and farmers regarding 
the harmful impact of herbicide agrochemicals on the environment, whereby herbicideresistant weeds can develop [12]. Allelopathy is a natural ecological function by which some organisms influence the activity of other organisms living in their surroundings. The influence is achieved by releasing secondary metabolites, also called allelochemicals [13-15]. The use of synthetic products is commonly discouraged due to their high cost and the ecological problems related to their usage. Scientists are trying to find new environmental solutions for plant growth enhancement that can ensure biosafety and eco-sustainability [16]. The utilization of allelopathic components as bioherbicides in agricultural systems can have many advantages over the usual, synthetic products $[17,18]$. Several compounds, including phenolics and their degradation products, were proven to have intense phytotoxic activity. Their significant inhibitory effects are seen on seed sprouting and disruption of root development [19]. Phenolic compounds are a major group of allelochemicals, ranging from phenols, flavonoids, hydroxycinnamic and benzoic acids, phenylpropanoids, coumarins, and tannins. They are produced by various plant species, while their inhibitory effects on crops and weeds have been well documented [12,20]. Allelochemicals are natural phytotoxins that offer a viable option for weed control in sustainable agroecosystems as an alternative to commercial herbicides. In the current study, the bioherbicidal potential of $S$. striata extracts were evaluated using an established method for allelopathic studies. The target plants were a crop species (Lepidium sativum L.) and two weed species (Chenopodium album L. and Malva sylvestris L.).

\section{Results and Discussion}

\subsection{Total Phenol Content (TPC) of Different Ecotypes of Scrophularia striata}

The results showed that the TPC values of $S$. striata in water extracts (WE) and hydroalcoholic extracts (HAE) were significantly different in comparison to one another. The highest TPC value was observed in the HAE obtained from the Pahleh ecotype ( $39.6 \mathrm{mg} / \mathrm{g}$ DW), whereas the lowest one was obtained in the WE from the Lizan ecotype $(28.3 \mathrm{mg} / \mathrm{g}$ DW) (Figure 1). This confirms that environmental conditions can influence the chemical characteristics of different ecotypes [21]. Indeed, variations in TPC reportedly exist in different ecotypes of legumes [22], Camellia sinensis (L.) Kuntze [23], Prunus cerasus L. [24], Cistus monspeliensis L. [25], and Zataria multiflora Boiss. [26]. Variations in quality and quantity of different secondary metabolites, including phenolics, under different extraction conditions, have been reported in olive pomace [27], Moringa oleifera Lam. [28], hazelnut skin [29], Hamelia patens Jacq. [30] and Sideritis trojana Bornm. [31]. Additionally, our results showed that the climatic conditions and the type of solvent can significantly affect the phytochemical composition of a plant extract. Previous research revealed the effects of different solvents on the phytochemical composition in extracts taken from different species, e.g., turmeric, lemon grass [32], Momordica charantia L. [33], kumquat [34], Phoenix sylvestris (L.) Roxb. fruit [35] and guava [36]. The quantity of polyphenols seems to be related to climatic variations. Actually, in warmer climates, phenolic compounds usually increase in amount, primarily due to the enhancement of photosynthetic activity [37,38]. Similar to our results, phytochemical variations have been observed in Medicago minima (L.) L. [39], Vitis vinifera L. [40], Aloe vera (L.) Burm.f. [41], Thymus capitatus (L.) Hoff. et Link. [42] and Cichorium spinosum L. [43], depending on geographic and climatic features. 


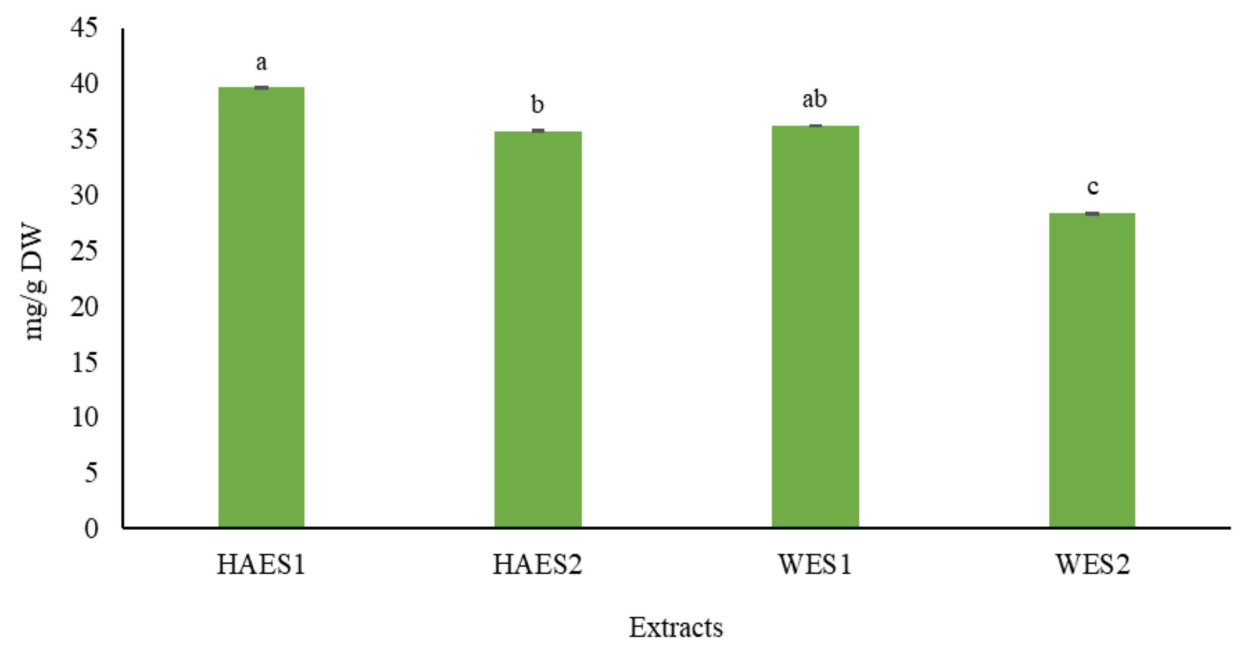

Figure 1. Total phenol content (TPC) (mg/g dry weight) of Scrophularia striata aerial parts extracts (HAES1: Hydroalcoholic extract Pahleh ecotype; HAES2: Hydroalcoholic extract Lizan ecotype; WES1: Water extract Pahleh ecotype; WES2: Water extract Lizan ecotype). Variables with different letters show statistically significant differences $(p \leq 0.05)$. The mean values with the same letters are not significantly different at $5 \%$ according to the LSD test.

\subsection{HPLC Analysis of Phenolic Compounds in Scrophularia striata}

HPLC analysis allowed us to determine quantitative values for seven phenolic compounds in the extracts of $S$. striata from the two ecotypes. The contents of vanillin $(0.12$ $\mathrm{mg} / \mathrm{g})$ and eugenol $(2.12 \mathrm{mg} / \mathrm{g})$ were higher in the Lizan extract, while rosmarinic acid $(2.65 \mathrm{mg} / \mathrm{g})$, hesperetin $(1.27 \mathrm{mg} / \mathrm{g})$, hesperedin $(1.04 \mathrm{mg} / \mathrm{g})$ and trans-ferulic acid $(0.56$ $\mathrm{mg} / \mathrm{g}$ ) were found in higher amounts in the Pahleh extract. Methanolic extracts were used for the preliminary identification of the target compounds in the two plant ecotypes. Caffeic acid was observed in trace amounts in the Lizan extract, while it appeared to be absent in the Pahleh extract (Table 1, Figure 2A,B).

Table 1. Polyphenol profile, as determined by HPLC in the two Scrophularia striata ecotypes.

\begin{tabular}{ccc}
\hline Compound $(\mathbf{m g} / \mathbf{g})$ & Lizan & Pahleh \\
\hline Caffeic acid & + & ND \\
Vanillin & $0.12 \pm 0.01$ & ND \\
trans-Ferulic acid & ND & $0.56 \pm 0.05$ \\
Hesperedin & ND & $1.04 \pm 0.04$ \\
Eugenol & $2.12 \pm 0.06$ & $1.88 \pm 0.03$ \\
Hesperetin & $0.53 \pm 0.02$ & $1.27 \pm 0.02$ \\
Rosmarinic acid & $0.88 \pm 0.04$ & $2.65 \pm 0.04$
\end{tabular}

+ means that this compound was detected in the extract but its content was very low (<limit of quantification) $\mathrm{ND}$, not detected.

Chromatograms are also presented in Figure 2A,B. Phenolic compounds are the most commonly reported metabolites that play roles in defensive mechanisms in higher plants. With variable levels of toxicity, they target plant cellular functions at multiple sites [44]. A previous research indicated how caffeic acid derivatives from Bellis perennis L. have potential allelopathic capacities. There were variations based on inhibitory effects on certain plants (e.g., Dactylis hispanica Roth) and stimulatory effects on others (e.g., Aegilops geniculate Roth) when considering the growth of herbal species [45]. When testing the allelopathic potential of different plant extracts, it is important to set up the most profitable extraction method to obtain the best yield of phytotoxic compounds. Thus, optimum extract concentration and type should be defined when acting against different weed species [46]. The contents and composition of different groups of secondary metabolites such as phenolic compounds regularly depend on extrinsic and intrinsic factors. Variations 
in specific metabolites may stem from climatic and cultivation features, origin and genetic factors, plant density, ontogenetic phases and seasonal variations, as well as extraction and drying procedures [47-49]. When in small amounts, polyphenols can act positively on seed sprouting. Nonetheless, at high doses, they may influence various metabolic and morphogenic processes in herbs by inducing oxidative stress [50]. The most active compounds as bio-herbicides are secondary metabolites, e.g., rosmarinic acid, pelargonic acid, carvacrol, eugenol, etc., which are currently used in weed management. Rosmarinic acid is a widespread polyphenol in many species of the Lamiaceae family. Its potential has been investigated in a wide range of biological contexts. Allelopathic effects of hesperidin have been mentioned in previous reports [51,52].



Figure 2. HPLC chromatograms of Pahleh extract (A) and Lizan extract (B) of Scrophularia striata.

The presence of vanillin in eggplant root exudates is reportedly regarded as an inhibitory effect and an obstacle to cropping [53]. It is known that vanillin has phytotoxic effects on goose grass (Eleusine indica L.), particularly on its plantlet growth. Furthermore, 
vanillin had strong inhibitory impacts on sprouting rates and the plantlet growth of lettuce and radish, but showed strong stimulatory effects on radix elongation in rice [54]. Ferulic and caffeic acids were measured in fresh aerial parts and roots of 10 cultivars of alfalfa. Bioassays on leaf litter leachates from all these cultivars showed variable degrees of inhibition on the seeding growth of Festuca arundinacea Schreb. and Sorghum x sudanense (Piper) Stapf. [55].

In a relevant study, the phytotoxic action of eugenol was examined on Lactuca sativa L., and the results showed a reduction in the number of normal plantlets, fresh weight, radix, and stem length, which might be due to the inhibitory effects on the cell cycle and the occurrence of chromosomal abnormalities [56]. Rosmarinic acid induced alterations in plasma membrane permeability in Phaeodactylum tricornutum Bohlin [57]. Eugenol was phytotoxic against a range of weeds such as Taraxacum officinale (L.) Weber ex F.H.Wigg. [58], Amaranthus retroflexus L. [59], Chenopodium album L. [60], Echinochloa crus-galli (L.) P.Beauv., Phalaris minor Retz., Ageratum conyzoides (L.) L., Leptochloa chinensis (L.) Nees, Bidens Pilosa L., and Commelina benghalensis L. [58], being promising as a bio-herbicide.

\subsection{Effects of Scrophularia striata Water Extracts on the Germination of Weeds}

In the present study, the germination percentage of seeds was reduced significantly $(p \leq 0.05)$ in response to almost all extracts, as compared to the control. All concentrations of WE, which had been obtained from the Pahleh accession, could significantly reduce the germination percentage of the two weeds, $M$. sylvestris and C. album $(p \leq 0.05)$. In the case of $M$. sylvestris, the first three concentrations reduced the germination percentage to zero. For C. album, however, the decrease was observed by up to $95 \%$, similar to the control treatment. In L. sativum, the $0.25 \%$ concentration did not affect the germination, but the other two concentrations ( 0.5 and $0.75 \%$ ) had stimulatory effects on the germination percentage of L. sativum. All concentrations of WE obtained from Lizan caused a significant decrease in seed germination (\%) $(p \leq 0.05)$ by up to $90-95 \%$ in M. sylvestris and C. album, whereas no significant decline was observed in the case of L. sativum germination $(p \leq 0.05)$ in comparison with the control. In other words, Lizan WE promoted L. sativum germination (Table 2).

A dose-dependent relationship was observed in regards to the inhibitory impact and elongation of radicle and stem. Previous research suggests that the disruption of mitochondrial respiration and oxidative pentose phosphate pathways are crucial mechanisms for the prevention of seed germination by phytochemicals [61]. Furthermore, phytotoxicity could be enhanced due to the synergistic impact of different phenolic compounds present in the extract [62].

A study on wheat showed that the foliar application of allelopathic WEs, and separately, seed pre-treatments in association with allelopathic WEs, can enhance grain weight and yield of plants, along with improvements in chlorophyll quantity under water-deficit stress. These observations can be explained by the accumulation of free proline in the leaf, total soluble phenolic compounds and a lower degree of relative membrane permeability in leaf cells [63]. In another research, the allelopathic activity was evaluated in aqueous extracts obtained from the roots and shoots of Argemone ochroleuca Sweet. Meanwhile, Farsetia aegyptia Turra, Salvia aegyptiaca L., Hordeum vulgare L., and Medicago sativa L. showed different responses to allelochemicals of $A$. ochroleuca. In a way, it could be said that the inhibition of seed germination is species-specific, while the concentration of extract, the type of plant organ and habitat conditions are likewise determinant. F. aegyptia seed germination is reportedly regarded as the most susceptible to different aqueous concentrations, whereas $H$. vulgare seed germination is the least susceptible [64]. 


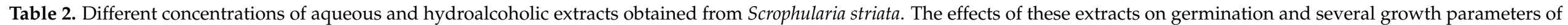
the examined species are shown. Mean values followed by the same letter are not significantly different at $p \leq 0.05$ (Tukey's test).

\begin{tabular}{|c|c|c|c|c|c|c|c|c|c|c|c|c|c|c|c|c|}
\hline \multirow[b]{2}{*}{ Concentration } & \multirow[b]{2}{*}{ Treatment } & \multicolumn{3}{|c|}{ Germination Percentage (\%) } & \multicolumn{3}{|c|}{ Root Length (cm) } & \multicolumn{3}{|c|}{ Stem Length $(\mathrm{cm})$} & \multicolumn{3}{|c|}{ Fresh Weight (mg) } & \multicolumn{3}{|c|}{ Dry Weight (mg) } \\
\hline & & $\begin{array}{c}M . \\
\text { sylvestris }\end{array}$ & C. album & L. sativum & $\begin{array}{c}M . \\
\text { sylvestris }\end{array}$ & C. Album & L. sativum & $\begin{array}{c}M . \\
\text { sylvestris }\end{array}$ & C. album & L. sativum & $\begin{array}{c}M . \\
\text { sylvestris }\end{array}$ & C. album & L. sativum & $\begin{array}{c}M . \\
\text { sylvestris }\end{array}$ & $\begin{array}{c}C . \\
\text { album }\end{array}$ & $\begin{array}{c}L . \\
\text { sativum }\end{array}$ \\
\hline 0 & Control-WE & $\begin{array}{l}53.33 \mathrm{~d} \\
5.8 \mathrm{de}\end{array}$ & $\begin{array}{l}63.33 \pm \\
5.8^{\mathrm{cd}}\end{array}$ & $\begin{array}{c}86.67 \pm \\
5.8^{\mathrm{ab}}\end{array}$ & $\begin{array}{l}3.63 \pm \\
0.25^{\mathrm{b}}\end{array}$ & $\begin{array}{l}5.47 \pm \\
0.66^{\mathrm{ab}}\end{array}$ & $\begin{array}{l}7.25 \pm \\
0.28^{\mathrm{a}} \\
\end{array}$ & $\begin{array}{l}4.43 \pm \\
0.47 \mathrm{ab}\end{array}$ & $\begin{array}{l}3.23 \pm \\
0.62 \mathrm{ab}\end{array}$ & $\begin{array}{l}5.21 \pm \\
0.36^{\mathrm{a}} \\
\end{array}$ & $\begin{array}{c}1100 \pm \\
205.02^{\mathrm{ab}}\end{array}$ & $\begin{array}{c}870 \pm \\
37.86^{\mathrm{a}-\mathrm{c}}\end{array}$ & $\begin{array}{c}1410 \pm \\
305.67^{\mathrm{a}}\end{array}$ & $\begin{array}{l}2.67 \pm \\
1.15^{\mathrm{b}}\end{array}$ & $\begin{array}{l}20 \pm \\
1.53^{\mathrm{a}} \\
\end{array}$ & $\begin{array}{l}4.33 \pm \\
2.31^{\mathrm{b}}\end{array}$ \\
\hline 0.25 & \multirow{4}{*}{ Pahleh WE } & $0 \pm 0^{1}$ & $\underset{\mathrm{h}-1}{8.33 \pm 5.8}$ & $\begin{array}{l}86.67 \pm \\
12.6^{\mathrm{ab}}\end{array}$ & $0 \pm 0^{g}$ & $\begin{array}{c}2.51 \pm \\
1.07^{\mathrm{b}-\mathrm{d}}\end{array}$ & $\begin{array}{l}2.28 \pm \\
0.54^{\mathrm{b}-\mathrm{f}}\end{array}$ & $0 \pm 0^{\mathrm{f}}$ & $2.65 \pm 1.0$ & $\begin{array}{l}2.36 \pm \\
0.95^{\mathrm{b}-\mathrm{e}}\end{array}$ & $0 \pm 0^{\mathrm{f}}$ & $630 \underset{b-f}{ \pm} 160$ & $\begin{array}{c}520 \pm \\
30.55^{\mathrm{b}-\mathrm{f}}\end{array}$ & $0 \pm 0^{\mathrm{b}}$ & $\begin{array}{l}3.67 \pm \\
2.08^{\mathrm{b}} \\
\end{array}$ & $\begin{array}{l}1.67 \pm \\
0.58^{\mathrm{b}}\end{array}$ \\
\hline 0.5 & & $0 \pm 0^{1}$ & $3.33 \pm 2.9$ & $\begin{array}{l}93.33 \pm \\
2.9^{\mathrm{a}}\end{array}$ & $0 \pm 0^{\mathrm{g}}$ & $\begin{array}{l}1.34 \pm \\
1.16^{\mathrm{c}-\mathrm{g}}\end{array}$ & $2.02 \underset{b-g}{ \pm} 0.31$ & $0 \pm 0^{\mathrm{f}}$ & $\begin{array}{l}1.95 \pm \\
1.69^{\mathrm{b}-\mathrm{f}}\end{array}$ & $\begin{array}{l}2.33 \pm \\
0.66^{\mathrm{b}-\mathrm{f}}\end{array}$ & $0 \pm 0^{\mathrm{f}}$ & $\begin{array}{c}470 \pm \\
430.62^{\mathrm{b}-\mathrm{f}}\end{array}$ & $\begin{array}{c}660 \pm \\
275.38^{\mathrm{b}-\mathrm{f}}\end{array}$ & $0 \pm 0^{\mathrm{b}}$ & $\begin{array}{l}4.33 \pm \\
3.78^{\mathrm{b}}\end{array}$ & $\begin{array}{l}2.67 \pm \\
2.08^{\mathrm{b}}\end{array}$ \\
\hline 0.75 & & $0 \pm 0^{1}$ & $6.67 \underset{\mathrm{i}-1}{ \pm} 2.9$ & $\begin{array}{c}95.00 \pm \\
5.0^{\mathrm{a}} \\
\end{array}$ & $0 \pm 0^{g}$ & $\begin{array}{c}0.60 \pm 0 \\
\mathrm{~d}-\mathrm{g}\end{array}$ & $\begin{array}{l}1.85 \pm \\
0.40^{\mathrm{b}-\mathrm{g}}\end{array}$ & $0 \pm 0^{\mathrm{f}}$ & $\begin{array}{l}1.35 \pm \\
0.54^{\mathrm{b}-\mathrm{f}}\end{array}$ & $1.94 \underset{\mathrm{b}-\mathrm{f}}{ \pm 0.71}$ & $0 \pm 0^{\mathrm{f}}$ & $50 \pm 20^{\text {ef }}$ & $\begin{array}{c}580 \pm \\
55.07^{\mathrm{b}-\mathrm{f}}\end{array}$ & $0 \pm 0^{\mathrm{b}}$ & $\begin{array}{l}0.3 \pm \\
0.17^{\mathrm{b}} \\
\end{array}$ & $\begin{array}{l}1.67 \pm \\
0.58^{\mathrm{b}}\end{array}$ \\
\hline 1 & & $\begin{array}{l}10.00 \pm \\
17.3^{\mathrm{h}-1}\end{array}$ & $3.33 \pm 2.9$ & $\begin{array}{l}73.33 \pm \\
10.4^{\mathrm{bc}}\end{array}$ & $\begin{array}{l}0.34 \pm \\
0.59^{\mathrm{d}-\mathrm{g}}\end{array}$ & $\begin{array}{l}1.37 \pm \\
1.18^{\mathrm{c}-\mathrm{g}}\end{array}$ & $\begin{array}{l}1.47 \pm \\
0.56^{\mathrm{c}-\mathrm{g}}\end{array}$ & $\begin{array}{l}0.54 \underset{ \pm}{ \pm} \\
0.94^{\mathrm{b}-\mathrm{f}}\end{array}$ & $\begin{array}{l}1.02 \pm \\
0.88^{\mathrm{b}-\mathrm{f}}\end{array}$ & $\begin{array}{l}2.73 \pm \\
0.92 \mathrm{ab}\end{array}$ & $\begin{array}{c}160 \pm \\
282.90^{\mathrm{d}-\mathrm{f}}\end{array}$ & $320 \underset{\mathrm{b}-\mathrm{f}}{ \pm} 280$ & $\begin{array}{c}720 \pm \\
160.73^{\text {a-e }}\end{array}$ & $\begin{array}{l}0.67 \mathrm{t} \\
1.15^{\mathrm{b}}\end{array}$ & $\begin{array}{l}1.67 \pm \\
1.52^{\mathrm{b}}\end{array}$ & $\begin{array}{l}3.33 \pm \\
1.15^{\mathrm{b}}\end{array}$ \\
\hline 0.25 & \multirow{4}{*}{ Lizan WE } & $\begin{array}{r}21.67 \pm \\
2.9^{\mathrm{g}-j}\end{array}$ & $\begin{array}{c}13.33 \pm \\
2.9^{\mathrm{h}-1}\end{array}$ & $\begin{array}{c}90.00 \pm \\
10.0^{\mathrm{ab}} \\
\end{array}$ & $\begin{array}{c}0.48 \pm \\
0.15^{\mathrm{d}-\mathrm{g}}\end{array}$ & $1.51 \underset{\mathrm{c}-\mathrm{g}}{ \pm} 0.31$ & $\begin{array}{l}.43 \pm \\
0.02^{\mathrm{a}}\end{array}$ & $\begin{array}{l}1.67 \pm \\
0.53^{\mathrm{b}-\mathrm{f}}\end{array}$ & $1.43 \underset{b-f}{ \pm} 0.61$ & $\underset{b-d}{2.50 \pm 0.11}$ & $\begin{array}{c}400 \pm \\
162.89^{\mathrm{b}-\mathrm{f}}\end{array}$ & $\begin{array}{c}510 \pm \\
109.70^{\mathrm{b}-\mathrm{f}}\end{array}$ & $\begin{array}{l}1150 \pm \\
45.83^{a}\end{array}$ & $\begin{array}{l}2.07 \pm \\
2.57^{\mathrm{b}}\end{array}$ & $\begin{array}{l}1.43 \mathrm{t} \\
1.40^{\mathrm{b}}\end{array}$ & $\begin{array}{l}90 \pm \\
0.58^{\mathrm{b}}\end{array}$ \\
\hline 0.5 & & $6.67 \underset{\mathrm{i}-1}{ \pm} 2.9$ & $\begin{array}{r}11.67 \pm \\
2.9^{\mathrm{h}-1}\end{array}$ & $\begin{array}{c}88.33 \pm \\
7.6^{\mathrm{ab}} \\
\end{array}$ & $\begin{array}{l}0.16 \pm \\
0.04 \mathrm{fg} \\
\end{array}$ & $\begin{array}{c}2.00 \pm \\
0.98^{\mathrm{b}-\mathrm{g}}\end{array}$ & $\begin{array}{l}6.47 \pm \\
1.40^{\mathrm{a}} \\
\end{array}$ & $\begin{array}{l}0.09 \pm \\
0.005^{\text {ef }}\end{array}$ & $\begin{array}{l}2.83 \pm \\
0.86^{\mathrm{ab}}\end{array}$ & $\begin{array}{l}2.00 \pm \\
0.46^{\text {bf }}\end{array}$ & $10 \pm 0.63^{\mathrm{f}}$ & $\begin{array}{c}760 \pm \\
283.61^{\mathrm{b}-\mathrm{d}}\end{array}$ & $\begin{array}{c}1140 \pm \\
115.33^{\mathrm{a}} \\
\end{array}$ & $0.1 \pm 0.1^{b}$ & $3 \pm \underset{b}{1.73}$ & $\begin{array}{l}80 \pm \\
0.58^{\mathrm{b}}\end{array}$ \\
\hline 0.75 & & $3.33 \pm 2.9$ & $6.67 \underset{\mathrm{i}-1}{ \pm} 2.9$ & $\begin{array}{c}93.33 \pm \\
7.6^{\mathrm{a}}\end{array}$ & $\begin{array}{l}0.87 \pm \\
1.03 \mathrm{cg}\end{array}$ & $\begin{array}{l}2.84 \underset{ \pm}{ \pm b c} \\
0.05^{\mathrm{bc}}\end{array}$ & $\begin{array}{l}3.80 \pm \\
1.03^{\mathrm{b}}\end{array}$ & $\begin{array}{l}1.73 \pm \\
1.58^{\mathrm{bff}}\end{array}$ & $\begin{array}{l}2.09 \pm \\
0.35^{\mathrm{bff}}\end{array}$ & $\begin{array}{l}1.99 \pm \\
0.68^{\mathrm{b}-\mathrm{f}}\end{array}$ & $\begin{array}{c}360 \pm \\
558.24^{\mathrm{b}-\mathrm{f}}\end{array}$ & $\begin{array}{c}590 \pm \\
219.32^{\mathrm{b}-\mathrm{f}}\end{array}$ & $\begin{array}{c}870 \pm \\
70.24^{\mathrm{a-c}}\end{array}$ & $\begin{array}{l}2.67 \pm \\
3.79^{\mathrm{b}}\end{array}$ & $\begin{array}{l}1.23 \mathrm{t} \\
1.53^{\mathrm{b}}\end{array}$ & $\begin{array}{l}70 \pm \\
0.58^{\mathrm{b}}\end{array}$ \\
\hline 1 & & $3.33_{\mathrm{j}-1} \pm 2.9$ & $6.67 \underset{\mathrm{i}-1}{ \pm} 2.9$ & $\begin{array}{c}95.00 \pm \\
8.7^{\mathrm{a}} \\
\end{array}$ & $\begin{array}{l}1.43^{ \pm} \\
1.25^{\mathrm{c}-\mathrm{g}} \\
\end{array}$ & $\begin{array}{l}1.12 \pm \\
0.90^{\mathrm{c}-\mathrm{g}}\end{array}$ & $3.80 \pm 1.31$ & $\begin{array}{l}2.03 \pm \\
1.76^{\mathrm{b}-\mathrm{f}} \\
\end{array}$ & $2.63 \underset{a-c}{ \pm} 0.61$ & $\begin{array}{l}2.50 \pm \\
0.10^{\mathrm{b}-\mathrm{d}}\end{array}$ & $\begin{array}{c}590 \pm \\
516.43^{\mathrm{b}-\mathrm{f}}\end{array}$ & $\begin{array}{c}610 \pm \\
220.30^{\mathrm{b}-\mathrm{f}}\end{array}$ & $\begin{array}{c}670 \pm \\
111.35^{\mathrm{b}-\mathrm{f}}\end{array}$ & $4 \pm 3.60^{\mathrm{b}}$ & $\begin{array}{l}2.67 \pm \\
2.08^{\mathrm{b}}\end{array}$ & $\begin{array}{l}3.67 \pm \\
0.58^{\mathrm{b}}\end{array}$ \\
\hline 0.25 & \multirow{4}{*}{$\begin{array}{l}\text { Pahleh } \\
\text { HAE }\end{array}$} & $0 \pm 0^{1}$ & $6.67 \underset{\mathrm{i}-1}{ \pm} 2.9$ & $\begin{array}{l}66.67 \pm \\
2.9^{\mathrm{cd}}\end{array}$ & $0 \pm 0 \mathrm{~g}$ & $\underset{\mathrm{d}-\mathrm{g}}{0.60 \pm 0.1}$ & $\begin{array}{l}3.72 \pm \\
0.13^{\mathrm{b}}\end{array}$ & $0 \pm 0^{\mathrm{f}}$ & $\begin{array}{l}0.41 \pm \\
0.10^{\mathrm{b}-\mathrm{f}}\end{array}$ & $\begin{array}{l}2.88 \pm \\
0.18^{\mathrm{ab}}\end{array}$ & $0 \pm 0^{\mathrm{f}}$ & $\begin{array}{l}3.33 \pm \\
2.08^{f}\end{array}$ & $960 \pm 40$ & $0 \pm 0^{\mathrm{b}}$ & $\begin{array}{l}0.2 \pm \\
0.1^{\mathrm{b}}\end{array}$ & $6 \pm 1^{b}$ \\
\hline 0.5 & & $0 \pm 0^{1}$ & $0 \pm 0^{1}$ & $\begin{array}{l}51.67 \pm \\
12.6^{\mathrm{de}}\end{array}$ & $0 \pm 0 \mathrm{~g}$ & $0 \pm 0 \mathrm{~g}$ & $\begin{array}{c}2.02 \pm \\
1.47^{\mathrm{b}-\mathrm{g}} \\
\end{array}$ & $0 \pm 0^{\mathrm{f}}$ & $0 \pm 0^{\mathrm{f}}$ & $\begin{array}{l}2.14 \pm \\
1.60^{\mathrm{b}-\mathrm{f}} \\
\end{array}$ & $0 \pm 0^{\mathrm{f}}$ & $0 \pm 0^{\mathrm{f}}$ & $\begin{array}{c}540 \pm \\
471.03^{\mathrm{b}-\mathrm{f}}\end{array}$ & $0 \pm 0^{\mathrm{b}}$ & $0 \pm 0^{\mathrm{b}}$ & $\begin{array}{l}3.67 \pm \\
2.31^{\mathrm{b}}\end{array}$ \\
\hline 0.75 & & $0 \pm 0^{1}$ & $0 \pm 0^{1}$ & $\underset{\mathrm{h}-1}{8.33} 5.8$ & $0 \pm 0 \mathrm{~g}$ & $0 \pm 0 \mathrm{~g}$ & $0 \pm 0.08^{\mathrm{fg}}$ & $0 \pm 0^{\mathrm{f}}$ & $0 \pm 0^{\mathrm{f}}$ & $0 \pm 0.09$ ef & $0 \pm 0^{\mathrm{f}}$ & $0 \pm 0^{\mathrm{f}}$ & $\begin{array}{l}1.67 \pm \\
1.15^{f}\end{array}$ & $0 \pm 0^{\mathrm{b}}$ & $0 \pm 0^{\mathrm{b}}$ & $0.1 \pm 0^{\mathrm{b}}$ \\
\hline 1 & & $0 \pm 0^{1}$ & $0 \pm 0^{1}$ & $0 \pm 0^{1}$ & $0 \pm 0^{g}$ & $0 \pm 0^{g}$ & $0 \pm 0^{g}$ & $0 \pm 0^{\mathrm{f}}$ & $0 \pm 0^{\mathrm{f}}$ & $0 \pm 0^{\mathrm{f}}$ & $0 \pm 0^{f}$ & $0 \pm 0^{\mathrm{f}}$ & $0 \pm 0^{\mathrm{f}}$ & $0 \pm 0^{\mathrm{b}}$ & $0 \pm 0^{\mathrm{b}}$ & $0 \pm 0^{\mathrm{b}}$ \\
\hline
\end{tabular}


Table 2. Cont.

\begin{tabular}{|c|c|c|c|c|c|c|c|c|c|c|c|c|c|c|c|c|}
\hline \multirow[b]{2}{*}{ Concentration } & \multirow[b]{2}{*}{ Treatment } & \multicolumn{3}{|c|}{ Germination Percentage (\%) } & \multicolumn{3}{|c|}{ Root Length (cm) } & \multicolumn{3}{|c|}{ Stem Length $(\mathrm{cm})$} & \multicolumn{3}{|c|}{ Fresh Weight (mg) } & \multicolumn{3}{|c|}{ Dry Weight (mg) } \\
\hline & & $\begin{array}{c}M . \\
\text { sylvestris }\end{array}$ & C. album & L. sativum & $\begin{array}{c}M . \\
\text { sylvestris }\end{array}$ & C. Album & L. sativum & $\begin{array}{c}M . \\
\text { sylvestris }\end{array}$ & C. album & L. sativum & $\begin{array}{c}M . \\
\text { sylvestris }\end{array}$ & C. album & L. sativum & $\begin{array}{c}M . \\
\text { sylvestris }\end{array}$ & $\begin{array}{c}\text { C. } \\
\text { album }\end{array}$ & $\begin{array}{c}. \\
\text { sativum } \\
\end{array}$ \\
\hline 0.25 & \multirow{4}{*}{$\begin{array}{l}\text { Lizan } \\
\text { HAE }\end{array}$} & $\begin{array}{l}26.67 \pm \\
5.8^{\mathrm{f}-\mathrm{h}}\end{array}$ & $\begin{array}{l}43.33 \pm \\
5.8^{\mathrm{ef}}\end{array}$ & $\begin{array}{c}76.67 \pm \\
2.9^{\mathrm{a}-\mathrm{c}}\end{array}$ & $\begin{array}{c}0.66 \pm \\
0.19^{\mathrm{c}-\mathrm{g}}\end{array}$ & $\begin{array}{c}0.80 \pm \\
0.35^{\mathrm{c}-\mathrm{g}}\end{array}$ & $\begin{array}{c}2.38 \pm \\
0.24^{\mathrm{be}}\end{array}$ & $\begin{array}{l}0.34 \pm \\
0.06^{\mathrm{c}-\mathrm{f}}\end{array}$ & $2.27 \underset{b-f}{ \pm} 0.21$ & $\begin{array}{l}2.25 \pm \\
0.40^{\mathrm{b}-\mathrm{f}}\end{array}$ & $\begin{array}{c}290 \pm \\
100.17^{\mathrm{b}-\mathrm{f}}\end{array}$ & $60 \pm \underset{\text { ef }}{15.82}$ & $\begin{array}{c}770 \pm \\
45.09^{\mathrm{b}-\mathrm{d}}\end{array}$ & $\begin{array}{l}3.23 \pm \\
2.25^{\mathrm{b}}\end{array}$ & $\begin{array}{l}1.33 \pm \\
0.58^{\mathrm{b}}\end{array}$ & $\begin{array}{l}6.67 \pm \\
1.15^{\mathrm{b}}\end{array}$ \\
\hline 0.5 & & $\begin{array}{l}16.67 \pm \\
5.8^{\mathrm{h}-1}\end{array}$ & $\begin{array}{l}40.00 \pm \\
10.0^{\mathrm{e}-\mathrm{g}}\end{array}$ & $\begin{array}{c}46.67 \pm \\
5.8^{\mathrm{e}}\end{array}$ & $\begin{array}{c}0.51 \pm \\
0.20^{\mathrm{d}-\mathrm{g}}\end{array}$ & $0.78 \underset{\mathrm{c}-\mathrm{g}}{ \pm} 0.11$ & $\begin{array}{c}0.48 \pm \\
0.17^{\mathrm{d}-\mathrm{g}}\end{array}$ & $\begin{array}{l}0.24 \pm \\
0.13^{\mathrm{d}-\mathrm{f}}\end{array}$ & $\begin{array}{l}0.52 \pm \\
0.10^{\mathrm{b}-\mathrm{f}}\end{array}$ & $\begin{array}{l}2.71 \pm \\
0.49 \mathrm{ab}\end{array}$ & $60 \pm 51.12$ & $3.8 \underset{\mathrm{f}}{ \pm} 1.06$ & $\begin{array}{c}640 \pm \\
81.44^{\mathrm{b}-\mathrm{f}}\end{array}$ & $\begin{array}{l}0.23 \pm \\
0.15^{\mathrm{b}}\end{array}$ & $\begin{array}{l}0.27 \pm \\
0.11^{\mathrm{b}}\end{array}$ & $\begin{array}{l}3.57 \pm \\
2.50^{\mathrm{b}}\end{array}$ \\
\hline 0.75 & & $\underset{\mathrm{i}-1}{5.0} \pm 5.0$ & $\underset{h-k}{20.00 \pm 0}$ & $\begin{array}{c}23.33 \pm \\
5.8^{\mathrm{g}-\mathrm{i}}\end{array}$ & $\begin{array}{l}0.14 \pm \\
0.16^{\mathrm{fg}}\end{array}$ & $\begin{array}{c}0.42 \pm \\
0.06^{\mathrm{d}-\mathrm{g}}\end{array}$ & $\begin{array}{c}1.38 \pm \\
1.43^{c-g}\end{array}$ & $\begin{array}{l}0.07 \pm \\
0.066^{\text {ef }}\end{array}$ & $\begin{array}{l}0.25 \pm \\
0.08 \text { df }\end{array}$ & $\begin{array}{l}1.44^{ \pm} \\
1.19^{\mathrm{b}-\mathrm{f}}\end{array}$ & $\begin{array}{l}1.43 \pm \\
2.23^{\mathrm{f}}\end{array}$ & $\begin{array}{l}0.73 \pm \\
0.30^{\mathrm{f}}\end{array}$ & $\begin{array}{c}680 \pm \\
581.74^{\text {bf }}\end{array}$ & $0.1 \pm 0.1^{\mathrm{b}}$ & $\begin{array}{l}0.27 \pm \\
0.21^{\mathrm{b}}\end{array}$ & $\begin{array}{c}30 \pm \\
36.06^{\mathrm{a}}\end{array}$ \\
\hline 1 & & $1.67 \underset{\mathrm{kl}}{ \pm} 2.9$ & $6.67 \pm 2.9$ & $6.67 \underset{i-1}{ \pm} 5.8$ & $\begin{array}{c}0.53 \pm \\
0.92^{\mathrm{d}-\mathrm{g}}\end{array}$ & $\begin{array}{l}0.11 \pm \\
0.02 \mathrm{fg}\end{array}$ & $\begin{array}{c}0.25 \pm \\
0.22^{\mathrm{e}-\mathrm{g}}\end{array}$ & $\begin{array}{l}0.90 \pm \\
1.56^{\mathrm{b}-\mathrm{f}}\end{array}$ & $\begin{array}{l}0.03 \pm \\
0.066^{\text {ef }}\end{array}$ & $\begin{array}{l}0.17 \pm \\
0.15^{\mathrm{d}-\mathrm{f}}\end{array}$ & $\begin{array}{c}210 \pm \\
369.50^{\mathrm{c}-\mathrm{f}}\end{array}$ & $0.23 \underset{\mathrm{f}}{ \pm} 0.11$ & $50 \pm \underset{\text { ef }}{42.10}$ & $1 \pm 1.73^{b}$ & $0.1 \pm 0^{\mathrm{b}}$ & $\begin{array}{l}0.07 \pm \\
0.11^{\mathrm{b}}\end{array}$ \\
\hline
\end{tabular}

Different letters show significant statistical difference $(p \leq 0.05)$. Three concentrations include $0.25,0.5$ and 0.75 were made from the stock solution $(100 \%=1)$. 
In another research, the aqueous leaf extract of Cymbopogon citratus (DC.) showed allelopathic effects on the seed germination of Bidens pilosa L. and B. subalternans DC. The research revealed that the aqueous extract of $C$. citratus significantly reduced the seed germination rate of B. pilosa and B. subalternans. The concentrations interfered, inversely and proportionally, while reducing the germination rate [65]. A previous study was conducted on the phytotoxic potentials of aqueous leaf extracts obtained from Artemisia absinthium L. and Psidium guajava L. Evaluations were aimed at various effects on seed germination, plantlet development, enzymatic and non-enzymatic antioxidants, photosynthetic pigments, and osmolytes of Parthenium hysterophorus L. Leaf extracts of both A. absinthium and $P$. guajava acted to limit seed germination and plantlet development, but increased antioxidant enzyme activities [66].

\subsection{Effects of Scrophularia striata Hydroalcoholic Extracts on the Germination of Weeds}

All three species in the present study were significantly affected by Pahleh HAE ( $p \leq 0.05)$. At high concentrations, germination was completely inhibited. On L. sativum, increasing the HAE Pahleh concentration caused a complete inhibition of germination. At a low concentration, Lizan HAE (0.25\%) acted to stimulate germination in all three species, but higher concentrations ( $0.5-0.75$ and $1 \%$ ) caused a decrease of up to $90 \%$ in germination (Table 2). The inhibitory impact was found to be dose-dependent and intensified, in parallel to the increase in concentration of the aqueous leaf extracts [67]. Similar inhibitory effects were caused by aqueous leaf extracts of Vitex negundo L. on Brassica chinensis L., L. sativa, Digitaria decumbens Stent, and Mimosa pudica L. [68]. Raoof and Siddiqui [69] reported that aqueous extracts from the leaves and stems of Tinospora cordifolia (2 and $4 \%)$ significantly inhibited the seed germination and seedling growth of C. album, C. murale L., Cassia tora L., and C. sophera L. The inhibition intensified by increasing the concentrations of various aqueous extracts [70]. Polyphenols have phytotoxic properties that are enacted by disrupting vital processes during the germination phase. Polyphenols can inhibit seed germination by inducing oxidative stress and bringing restrictions on nutrient reserve mobilization. This is partly due to the inhibition of the activities of $\alpha$-amylase and gibberellic acid [71].

The allelopathic activities of Tectona grandis L.f. [72], Albizia procera (Roxb.) Benth. [73], and Acacia nilotica (L.) Delile [74] were studied in regards to the sprouting and development of soybean. Accordingly, the leaf extracts of all these species at low doses had stimulatory effects on germination, growth, chlorophyll, protein, carbohydrates, and proline contents in soybean plants. At higher concentrations, however, there was a decrease in all of the measured attributes [75]. In some respects, the aforementioned research yielded similar results, thereby validating previous observations reported by Wang et al. [76], Khang et al. [77], Nouri et al. [78], and Al-Harbi, [79]. Allelochemicals have inhibitory effects and sometimes lethal impacts on seed germination, growth, and development of plants. According to these citations, lower concentrations prevent germination to various extents, which is probably due to the lower contents of allelochemicals, while higher concentrations cause lethal impacts on seed sprouting.

In a previous research, the impacts of several concentrations of a hydro-alcoholic extract of St. John's wort (Hypericum perforatum L.) and sage (Salvia officinalis L.) were evaluated on seed sprouting (\%) and germination rate of two weed species, A. retroflexus and Portulaca oleracea L. Their results revealed that the extract of St. John's wort and sage had notable inhibitory effects on the sprouting of $A$. retroflexus seeds, but not on P. oleracea seeds $[80,81]$. In another research, the comparative allelopathic potentials of WE and HAE extracts of Prangos ferulacea (L.) Lindl. were studied on different plant organs (i.e., flower, stem, and leaf). The effects were investigated on the proline content, seed sprouting, and plantlet development of Trifolium resupinatum L. [82]. The results showed that the HAE extract showed maximum phenol and flavonoid contents, along with maximum phytotoxic impacts on T. resupinatum. Notably, it reduced seed sprouting and the plantlet development of T. resupinatum, while enhancing the proline content. These 
findings indicate that hydroalcoholic extracts can induce stronger oxidative stress on $T$. resupinatum [82].

\subsection{Effects of Water Extracts Obtained from Scrophularia striata on the Root Length and Stem Length of Weeds}

As shown in Table 2, the roots reached maximum length in the control treatment of all three species. However, root length decreased significantly $(p \leq 0.05)$ in all three examined species in response to all concentrations of WE from the Pahleh accession. The WE from the Lizan ecotype reduced significantly the root length in M. sylvestris and C. album ( $p \leq$ 0.05). In L. sativum, low concentrations ( 0.25 and $0.5 \%)$ of Lizan WE did not reduce the root length, but higher concentrations were significantly effective $(p \leq 0.05)$ (Table 2$)$.

The stem length of some plants was affected significantly $(p \leq 0.05)$ at almost all concentrations. The Pahleh WE, at the three concentrations, could reduce M. sylvestris stem length significantly, although none of its concentrations could affect C. album stem length. The physiological response of L. sativum to Pahleh WE was also variable at different concentrations (Table 2). In one relevant study, the aqueous extracts of Rhazya stricta Decne. showed allelopathic activity while affecting Salsola villosa Schult. roots and stem length. More specifically, exudates from $R$. stricta leaves were observed to reduce the content of membrane polyunsaturated fatty acids and phospholipids, while hampering membrane functions and photosynthetic capacity. They also restricted the growth of $S$. villosa roots and stems [83]. Another study on aqueous leaf extracts of Prosopis juliflora (Sw.) DC. showed pronounced inhibitory effects on the root length of Triticum aestivum L. [84]. In another study, the WE of Eclipta alba (L.) leaves showed inhibitory effects on the root radicle length and stem length of $C$. tora and C. sophera [85]. An experiment was carried out to investigate the allelopathic activity of $T$. cordifolia extracts on plantlet development in C. album, C. murale, $C$. tora, and C. sophera. It was found that WE from the roots inhibited the growth of seedlings, roots, and shoots [69].

\subsection{Effects of Scrophularia striata Hydroalcoholic Extracts on the Root and Stem Length of Weeds}

All concentrations of HAE from the Pahleh ecotype significantly reduced the root length in all the examined species ( $p \leq 0.05)$. In $M$. sylvestris, the root length ceased to exist in response to all concentrations of the extracts. In C. album, high concentrations of HAE $(0.5-0.75$ and $1 \%)$ reduced the root length to zero. This happened almost similarly in the case of L. sativum, although the decrease was mostly in response to the $1 \%$ concentration of Pahleh HAE. However, Lizan HAE could not affect the root length of M. sylvestris, though it did reduce the root length of the two other plant species (C. album and L. sativum) at all concentrations. In applying the treatments on C. album, a more dramatic decrease in root length was observed as the concentration of Lizan HAE increased. Evaluations of the stem length under different treatments and concentrations showed that the Pahleh HAE reduced significantly the stem length in $M$. sylvestris and could totally prevent the stem growth. On L. sativum, two concentrations of this HAE $(0.75$ and $1 \%)$ reduced significantly the stem length to zero $(p \leq 0.05)$. The Lizan HAE extract, at 0.75 and $1 \%$ concentrations, reduced significantly the stem length in $M$. sylvestris and L. sativum, respectively ( $p \leq$ 0.05) (Table 2). In a relevant study, the allelopathic potentials of hydroalcoholic foliar extracts of Myrcia guianensis (Aubl.) DC. were studied on the sorghum root growth. The results showed that HAE can have stronger inhibitory effects than methanol and aqueous extracts [86]. In another research, the allelopathic activity of Mansoa standleyi (Steyerm.) A.H.Gentry was investigated by comparing the impacts of the HAE on M. pudica roots, hypocotyl sprouting and development. It was observed that the HAE can inhibit the radicle growth and hypocotyl germination/development [87]. Researchers revealed that the HAE of Withania somnifera (L.) Dunal can have promising allelopathic properties by affecting significantly the seed germination and root elongation. Cicer arietinum L. and T. aestivum were mostly affected in a concentration-dependent manner by the W. somnifera extract [88]. Caffeic acid and ferulic acid, as phenolic compounds, notably reduced the root growth of mung bean and maize $[89,90]$. Compounds that can potentially induce inhibitory effects 
on seed germination and other growth factors are generally identified as phenolic acids. In this regard, $p$-coumaric, ferulic, vanillic and syringic acids are constituents of $V$. negundo leaf extracts. These compounds have shown both inhibitory and stimulatory effects on weeds, depending on the situation. Alterations in chlorophyll production, respiration, protein synthesis, hormonal balance and water content might be parameters influencing the allelopathic potential of extracts [91,92]. Abdelmigid and Morsi [93] reported that Eucalyptus globulus Labill. extract can reduce protein content in the root and stem of finger millet (Eleusine coracana (L.) Gaertn.).

\subsection{Effects of Scrophularia striata Water Extracts on the Fresh and Dry Weight of Weeds}

Lizan WE reduced significantly the seedling fresh weight of M. sylvestris and L. sativum $(p \leq 0.05)$ at a concentration of 0.5 and 1\%, respectively. The WE of the Pahleh ecotype reduced the $M$. sylvestris fresh weight by $100 \%$ when used at concentrations of $0.25,0.5$, and $0.75 \%$. Regarding C. album fresh weight, the highest degree of reduction (94\%) occurred in response to the $0.75 \%$ concentration. Additionally, regarding L. sativum fresh weight, all concentrations of the extracts caused a significant decrease $(P \leq 0.05)$, except for the $1 \%$ concentration (Table 2 ). Our results showed that the Pahleh extract can inhibit the germination and hamper the initial growth parameters more strongly in many cases, mostly because of its richer content in phenolic compounds such as trans-ferulic acid $(0.56 \mathrm{mg} / \mathrm{g})$, hesperedin $(1.04 \mathrm{mg} / \mathrm{g})$, hesperetin $(1.27 \mathrm{mg} / \mathrm{g})$, and rosmarinic acid (2.65 mg/g) (Table 1).

Dry weights of the different species followed nearly the same trend. Lizan WE reduced significantly the seedling dry weight of $C$. album at all concentrations $(p \leq 0.05)$. Pahleh WE reduced the dry weight of all plants. These reductions were all significant $(p \leq 0.05)$ considering $C$. album (Table 2). In almost all cases, high concentrations of the aqueous extracts reduced the fresh and dry weight of seedlings. Research on the allelopathic potential of aqueous extracts of peppermint revealed that the inhibitory impacts on tomato biomass occurred mostly in response to the application of $10 \%$ extract [71].

The aerial parts and root extracts of Haloxylon aphyllum (Minkw.) reduced the seedling fresh and dry biomass of Agropyron elongatum (Host.) and A. desertorum (Fisch.) [62]. Other researchers stated that the aqueous extracts of $T$. cordifolia (from the leaf and stems of the plant) reduced the dry weights of some weed plants [69]. In another study, C. album and Coronopus didymus (L.) Sm. fresh biomass was reduced by 100 and 90\%, respectively, as a result of the allelopathic effects of sorghum (15 L/ha) [94]. In another investigation, sunflower aqueous extract (100\% concentration) reduced the total dry weight of weeds, including Avena fatua L., Phalaris minor Retz., C. album, and C. didimus [95].

Low concentrations of benzoic, coumaric, gallic and caffeic acids can increase the cell division and cell enlargement by accelerating the rate of mitosis and cellulose synthesis [96], thereby providing an opportunity for a better growth of maize seedlings. An increase in protein content might also be due to the presence of phenolic compounds which help to assimilate the amino acids into structural protein-based building blocks in the plant [97]. Chlorogenic, isochlorogenic, neochlorogenic, and dicaffeoylquinic acids can be present in allelopathic extracts. They assist in preventing the production of ROS when applied at lower concentrations. In contrast, applying aqueous extracts that contain $p$-coumaric acid at low concentrations can strongly activate indolacetic acid (IAA). Cinnamic acid at low concentrations can prevent IAA from degradation and promote seedling growth. Phenolic compounds, having a variety of functions, act predominantly as antioxidant agents and reduce the harmful effects of reactive oxygen species [98,99].

\subsection{Effects of Scrophularia striata Hydroalcoholic Extracts on the Fresh and Dry Weight of Weeds}

In L. sativum, Lizan HAE caused a significant $(p \leq 0.05)$ reduction in fresh weight in response to all concentrations. The Lizan HAE at $1 \%$ concentration reduced the fresh weight of C. album to zero. Furthermore, the HAE at 0.75 and $1 \%$ concentrations reduced the dry weight to zero in M. sylvestris and C. album, respectively. The HAE of the Pahleh ecotype reduced the L. sativum fresh weight significantly $(p \leq 0.05)$ when used at concentrations of 
$0.5 \%, 0.75 \%$ and $1 \%$ (Table 2 ). In a relevant study, the results indicated how HAEs, which had been obtained from the leaf and stem of Solidago gigantea Aiton, affect the dry biomass of E. crus-galli and A. retroflexus. The decrease in dry biomass in these weeds depended on the concentration of extracts obtained from S. gigantea. The dry weights of E. crus-galli and $A$. retroflexus were reduced most notably by two concentrations, $12.5 \%$ and $10 \%$ [100]. Studies on Protosiphom botryoides Klebs-I. indicated that the growth rate and dry weight decrease in response to Cestrum parqui (Lam.) L'Hér. hydroalcoholic extract, especially at the lowest concentration [101]. Ravlić et al. [102] reported the inhibitory effects of fresh and dry biomass of scentless mayweed on the germination of cereals. Variations in the diffusion pattern of soluble allelochemicals during extraction can be a reason for differences in the inhibitory effects of extracts [103].

\section{Materials and Methods}

\subsection{Plant Collection Area}

S. striata is mostly distributed in the province of Ilam, a mountainous region in the western part of Iran [104]. For the purpose of sampling, habitats of the herb were selected via field observations. Subsequently, two distinct regions were selected based on ecological factors. These regions were, namely, Lizan (Longitude: $46^{\circ} 8^{\prime} 19.42^{\prime \prime} \mathrm{E}$; Latitude: $33^{\circ} 34^{\prime} 2.16^{\prime \prime} \mathrm{N}$ ) and Pahleh (Longitude: $46^{\circ} 50^{\prime} 43.16^{\prime \prime} \mathrm{E}$; Latitude: $33^{\circ} 2^{\prime} 27.28^{\prime \prime} \mathrm{N}$ ), with a distance of $149 \mathrm{~km}$ apart from each other. The location of the studied sites is provided in Figure 3.
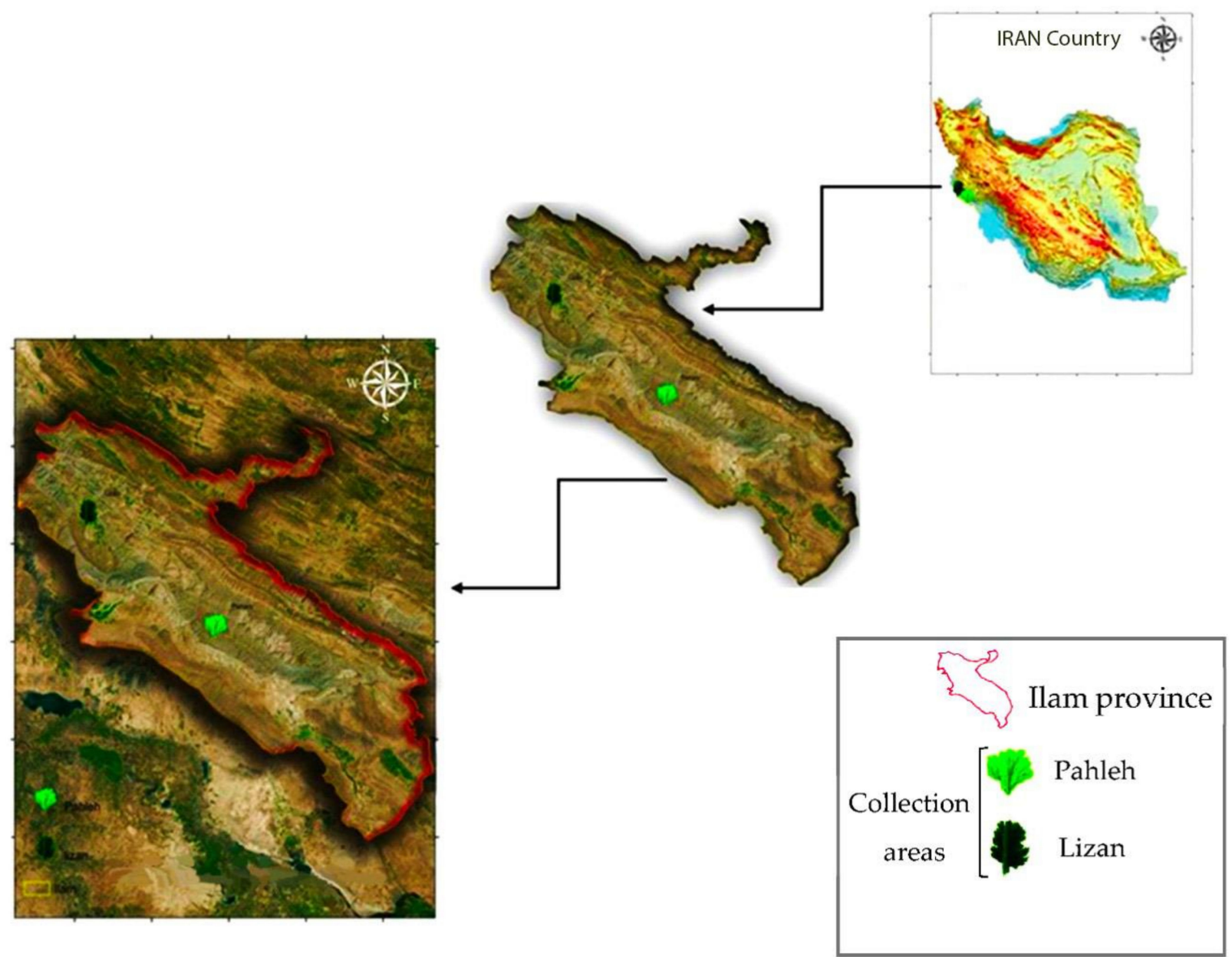

Figure 3. Different sampling locations of Scrophularia striata from Ilam province (the two sampling regions, Pahleh and Lizan, are shown in the map). 


\subsection{Plant Material}

Aerial parts of $S$. striata were collected from two regions of Ilam province, namely, Pahleh (S1) and Lizan (S2). Sampling was carried out in May 2019. Aerial parts that were in the fruit set stage were used for extraction and phytochemical investigations. The plant materials were dried in the room temperature for one week. The seeds of two universally aggressive agricultural weeds (Malva sylvestris L. and Chenopodium album L.) were collected from the Agricultural Research Station of Shiraz University. Additionally, L. sativum seeds were bought from the market. As a widespread crop species, L. sativum is a leafy edible plant and is commonly used as a test species for initial screening in laboratory bioassays aimed at evaluating the phytotoxic effects of allelochemicals and/or natural phytotoxins [105].

\subsection{Preparation of Aqueous and Hydroalcoholic Extracts for Allelopathy Experiments}

To make the required extracts, the reflux apparatus was used according to the relevant literature and methodology, with specific changes [106]. Briefly, the dried and powdered aerial parts of S. striata (50 g from Pahleh ecotype and $50 \mathrm{~g}$ from Lizan ecotype) were used separately to make a stock aqueous extract (WE) solution. Additionally, $50 \mathrm{~g}$ dry aerial parts of the Pahleh ecotype and $50 \mathrm{~g}$ dry aerial parts of the Lizan ecotype were added to a mixture of water: ethanol with $96 \%$ purity $(50: 50)(500 \mathrm{~mL})$. These were collectively placed in a round-bottomed laboratory balloon $(1000 \mathrm{~mL})$ to prepare the hydroalcoholic extract (HAE). Then, the balloons were placed in heating mantles, and the extraction process took $2 \mathrm{~h}$. All assays were performed in triplicate. Filtrates of stock extracts were obtained by filter paper (Whatman No. 2) and were appropriately diluted to give final concentrations of $0.25,0.5,0.75$, and $1 \%(v / v)$. Distilled water and water-ethanol mixtures were used as the control.

\subsection{Extract Preparation for Phenolic Compounds Determination}

The dry aerial parts of the two mentioned ecotypes were powdered. For each ecotype, $2 \mathrm{~mL}$ of solvent ( $85 \%$ methanol $+15 \%$ acetic acid) was added to $0.2 \mathrm{~g}$ of powder. The tubes were filled with nitrogen gas to prevent the oxidation of the phenolic compounds. They were settled at $-20^{\circ} \mathrm{C}$ in the dark for $24 \mathrm{~h}$. After one day, the tubes were put in an ultrasonic bath for $15 \mathrm{~min}$. Then, the tubes were centrifuged for $20 \mathrm{~min}\left(4^{\circ} \mathrm{C}, 10,000 \mathrm{rpm}\right)$, the supernatant was separated, and $n$-hexane (which occurred in the same volume as the supernatant) was added. Then, the tubes were vortexed for 15 secs and centrifuged again for $10 \mathrm{~min}\left(10,000 \mathrm{rpm}, 4^{\circ} \mathrm{C}\right)$. At this stage, the underside phase consisted of polyphenols, which can be separated by a syringe. A syringe filter ( 0.45 Micron) was used to remove impurities. Extracts were kept in special vials in the refrigerator until HPLC analysis.

\subsection{Determining the Total Phenol and Phenolic Compounds Profile}

The total phenolic content (TPC) of the aqueous and hydroalcoholic extracts were determined using the method of Mahdavikia and Saharkhiz [71]. Briefly, the calibration curve was based on a mixture, including $1 \mathrm{~mL}$ ethanolic solution of gallic acid (0.025-0.400 $\mathrm{mg} / \mathrm{mL}), 5 \mathrm{~mL}$ diluted Folin-Ciocalteu reagent, and $4 \mathrm{~mL}$ sodium carbonate $(0.7 \mathrm{M})$. The absorbance of TPC was measured by using a Hitachi U-2000 spectrophotometer at $765 \mathrm{~nm}$. For separation, identification, and quantification of the phenolic components of $S$. striata extracts, an HPLC analysis was carried out on an Agilent 1200 series (USA), equipped with a reverse phase Zorbax Eclipse (XDB)-C18 column $(10 \mathrm{~cm} \times 5 \mathrm{~mm}$ i.d.; $150 \mathrm{~mm}$ film thickness), and with a photodiode array detector (PAD).

To prepare the injectable extracts, $0.02 \mathrm{~g}$ of the vacuum-dried residue of the plant extract was dissolved in $1 \mathrm{~mL}$ of methanol. The aliquots were filtered through a $0.2 \mu \mathrm{m}$ membrane millipore chromatographic filter and then $20 \mu \mathrm{L}$ of the solution was injected into the HPLC system. The flow rate was set at $1 \mathrm{~mL} \mathrm{~min}{ }^{-1}$. The elution was monitored at 280 and $320 \mathrm{~nm}$. A gradient elution was selected to achieve maximum separation and sensitivity. The elution was performed by changing the proportion of solvent A (formic 
acid $1 \%$ in deionized water) to solvent $B$ (methanol $(v / v)$ ) as follows: methanol: formic acid 1\% (10:90), at 0 min; methanol: formic acid 1\% (25:75), at $10 \mathrm{~min}$; methanol: formic acid 1\% (60:40), at $20 \mathrm{~min}$ and, finally, methanol: formic acid 1\% (70:30), at $30 \mathrm{~min}$. The total running time was $40 \mathrm{~min}$. The column temperature was $30^{\circ} \mathrm{C}$. Compounds were identified by comparison with analytical standards and by drawing calibration curves. The analytical standards were caffeic acid, vanillin, trans-ferulic acid, hesperedin, eugenol, hesperetin, and rosmarinic acid. All were purchased from Sigma.

\subsection{Germination Bioassay}

The phytotoxic effects of the two types of extracts, which had been obtained from two different ecotypes, Pahleh and Lizan, were evaluated. These effects were monitored on the crop plant and compared to the effects on weed species. Sprouting assessments were carried out for each $S$. striata extract as follows. Concerning seed size, 20 sterilized M. sylvestris, C. album, and L. sativum seeds were placed on Whatman No. 1 filter paper in sterile Petri dishes ( $9 \mathrm{~cm}$ diameter). Five $\mathrm{ml}$ of the extract solutions from four concentrations of stock solution $(0.25,0.5,0.75$, and $1.0 \%)$ were included in each plate. Distilled water and hydroalcoholic solution (ethanol 50\%) were used as the control. The plates were placed in a controlled chamber (1300 STC Mod, Noor-Sanat-Ferdows Company, Karaj, Iran) $\left(26{ }^{\circ} \mathrm{C}\right.$ during the day and $22{ }^{\circ} \mathrm{C}$ at night, $16 \mathrm{~h}$ light and $8 \mathrm{~h}$ dark, 4000 lux) and germination tests took up to about two weeks. To stop evaporation, the plates were closed up with parafilm and then placed in the growth chamber. The plates were examined every day and moistened as required. Three replications were used for each treatment. After about two weeks, the seeds that showed radix unfolding $(1 \mathrm{~mm})$ were noted as sprouted. The final germination percentage (FGP) was calculated for each trial according to a method used by Mouradi et al. [107]. Moreover, the length of the seedlings primary radix and the stem length were measured by a ruler. Dry and fresh weights were measured at the end of the test with a four-digit scale.

\subsection{Statistical Analysis}

The investigation was arranged based on a completely randomized factorial design with three replications for each treatment. The treatments were two types of $S$. striata extracts (WE and HAE extracts) and three different plant species (L. sativum, C. album, and M. sylvestris). Each extract had four concentrations. Distilled water and a water-ethanol solution (50:50) were used as control groups. These treatments were assumed to affect the germination percentage and several other factors of seedling growth. The normality test and data analyzing were carried out by using Minitab statistical software (version17) to check data normality. The data, as mean values, were compared by using Tukey's analyzed test at the $5 \%$ level.

\section{Conclusions}

The allelopathic effects of the aqueous and hydroalcoholic extracts of $S$. striata were documented after being obtained from two different ecotypes (Pahleh and Lizan). Inhibitory effects on seed germination and seedling growth were observed in L. sativum, C. album, and M. sylvestris. High concentrations of extracts yielded the best results but, in many cases, acted in a species-specific manner. The extracts of $S$. striata could have allelopathic effects on other weeds and horticultural plants because they are capable of substantial effects on weeds, thereby having the capacity to contribute to an environmentally friendly approach to weed control. These extracts deserve further tests on other weeds. Different variations in the components of $S$. striata extracts can be valuable from a phytotoxic point of view to formulate natural herbicides. More research is required in this regard to operationalize in agriculture the allelochemicals that are currently identified in hydroalcoholic extracts obtained from S. striata. Indeed, the evaluation of their effects against weed species under field conditions can support their use as natural herbicides. 
Author Contributions: Supervision: A.K. and F.M.; data curation: S.S.M. and T.M.H.; funding acquisition: F.M. writing-review and editing: A.K. and F.M.; investigation, methodology: S.S.M., T.M.H. and S.A.; validation, writing - original draft preparation, A.K., F.M., S.S.M. and T.M.H. All authors have read and agreed to the published version of the manuscript.

Funding: No funding to declare.

Institutional Review Board Statement: Not applicable.

Informed Consent Statement: Not applicable.

Data Availability Statement: Not applicable.

Acknowledgments: The authors thank anonymous reviewers and editors for providing valuable suggestions that improved the quality of the manuscript. We also would like to thank Mohsen Hamedpour-Darabi for editing the English language of the article.

Conflicts of Interest: The authors declare no conflict of interest.

\section{References}

1. Ghashghaii, A.; Hashemnia, M.; Nikousefat, Z.; Zangeneh, M.M.; Zangeneh, A. Wound healing potential of methanolic extract of Scrophularia striata in rats. Pharm Sci. 2017, 23, 256-263. [CrossRef]

2. Shahbazi, Y. Antibacterial and Antioxidant Properties of Scrophularia Striata Boiss. Methanolic Extract. J. Pure Appl. Microbiol. 2017, 11, 1435-1441. [CrossRef]

3. Richman, A.D.; Broothaerts, W.; Kohn, J.R. Self-incompatibility RNases from three plant families: Homology or convergence? Am. J. Bot. 1997, 84, 912-917. [CrossRef] [PubMed]

4. Rezaie-Tavirani, M.; Mortazavi, S.A.; Barzegar, M.; Moghadamnia, S.H.; Rezaee, M.B. Study of anticancer property of Scrophularia striata extract on the human astrocytoma cell line (1321). IJPR. 2010, 9, 403.

5. Falahi, H.; Sharifi, M.; Maivan, H.Z.; Chashmi, N.A. Phenylethanoid glycosides accumulation in roots of Scrophularia striata as a response to water stress. Environ. Exp. Bot. 2018, 147, 13-21. [CrossRef]

6. Beshamgan, E.S.; Sharifi, M.; Zarinkamar, F. Crosstalk among polyamines, phytohormones, hydrogen peroxide, and phenylethanoid glycosides responses in Scrophularia striata to Cd stress. Plant Physiol. Biochem. 2019, 143, 129-141. [CrossRef]

7. Tamri, P. A mini-review on phytochemistry and pharmacological activities of Scrophularia striata. J. Herbmed Pharm. 2019, 8, 85-89. [CrossRef]

8. Zargoosh, Z.; Ghavam, M.; Bacchetta, G.; Tavili, A. Effects of ecological factors on the antioxidant potential and total phenol content of Scrophularia striata Boiss. Sci. Rep. 2019, 9, 1-15. [CrossRef]

9. Azadmehr, A.; Oghyanous, K.A.; Hajiaghaee, R.; Amirghofran, Z.; Azadbakht, M. Antioxidant and neuroprotective effects of Scrophularia striata extract against oxidative stress-induced neurotoxicity. Cell. Mol. Neurobiol. 2013, 33, 1135-1141. [CrossRef]

10. Farooq, N.; Abbas, T.; Tanveer, A.; Jabran, K. Allelopathy for weed management. Co-Evol. Second. Metab. 2020, 505-519. [CrossRef]

11. Cullen, M.G.; Thompson, L.J.; Carolan, J.C.; Stout, J.C.; Stanley, D.A. Fungicides, herbicides and bees: A systematic review of existing research and methods. PLoS ONE 2019, 14, e0225743. [CrossRef] [PubMed]

12. Perveen, S.; Yousaf, M.; Mushtaq, M.N.; Sarwar, N.; Khan, M.Y.; Mahmood, S. Bioherbicidal potential of some allelopathic agroforestry and fruit plant species against Lepidium sativum. Plant Soil Environ. 2019, 38, 11-18.

13. Aslam, F.; Khaliq, A.; Matloob, A.; Tanveer, A.; Hussain, S.; Zahir, Z.A. Allelopathy in agro-ecosystems: A critical review of wheat allelopathy-concepts and implications. Chemoecology 2017, 27, 1-24. [CrossRef]

14. Yuan, Z.; Zheng, Z.; Zhao, Y.; Liu, Y.; Zhou, S.; Wei, C.; Hu, Y.; Shao, H. Phytotoxic compounds isolated from leaves of the invasive weed Xanthium spinosum. Molecules 2018, 23, 2840. [CrossRef]

15. Nawaz, H.; Aslam, M.; Muntaha, S.T. Effect of Solvent Polarity and Extraction Method on Phytochemical Composition and Antioxidant Potential of Corn Silk. Free Radic. Antioxid. 2019, 9, 5-11. [CrossRef]

16. Bajwa, A.A.; Nawaz, A.; Farooq, M. Allelopathic Crop Water Extracts Application Improves the Wheat Productivity Under Low and High Fertilizer Inputs in a Semi-Arid Environment. Int. J. Plant Prod. 2019, 14, 1-13. [CrossRef]

17. Pouresmaeil, M.; Nojadeh, M.S.; Movafeghi, A.; Maggi, F. Exploring the bio-control efficacy of Artemisia fragrans essential oil on the perennial weed Convolvulus arvensis: Inhibitory effects on the photosynthetic machinery and induction of oxidative stress. Ind. Crops Prod. 2020, 155, 112785. [CrossRef]

18. Elshamy, A.I.; Abd-ElGawad, A.M.; El Gendy, A.E.N.G.; Assaeed, A.M. Chemical characterization of Euphorbia heterophylla L. essential oils and their antioxidant activity and allelopathic potential on Cenchrus echinatus L. Chem. Biodivers. 2019, 16, e1900051. [CrossRef]

19. Abd-ElGawad, A.M.; Elshamy, A.I.; Al-Rowaily, S.L.; El-Amier, Y.A. Habitat affects the chemical profile, allelopathy, and antioxidant properties of essential oils and phenolic enriched extracts of the invasive plant Heliotropium curassavicum. Plants 2019, 8, 482. [CrossRef]

20. John, J.; Sarada, S. Role of phenolics in allelopathic interactions. Allelopath. J. 2012, 29, 215-230. 
21. Davazdahemami, S.; Sefidkon, F.; Jahansooz, M.; Mazaheri, D. Chemical Composition of the Essential Oils from Foliages and Seeds of Ajowan (Trachyspermum ammi (L.) Sprague) in two planting dates (spring and summer). J. Essent. Oil Bear. Plants 2011, 14, 639-642. [CrossRef]

22. Fratianni, F.; Cardinale, F.; Cozzolino, A.; Granese, T.; Albanese, D.; Di Matteo, M.; Nazzaro, F. Polyphenol composition and antioxidant activity of different grass pea (Lathyrus sativus), lentils (Lens culinaris), and chickpea (Cicer arietinum) ecotypes of the Campania region (Southern Italy). J. Funct. Foods 2014, 7, 551-557. [CrossRef]

23. Zhang, L.; Santos, J.S.; Cruz, T.M.; Marques, M.B.; do Carmo, M.A.V.; Azevedo, L.; Granato, D. Multivariate effects of Chinese keemun black tea grades (Camellia sinensis var. sinensis) on the phenolic composition, antioxidant, antihemolytic and cytotoxic/cytoprotection activities. Food Res. Int. 2019, 125, 108516. [CrossRef] [PubMed]

24. Pedisić, S.; Zorić, Z.; Repajić, M.; Elez Garofulić, I.; Čosić, Z.; Dragović-Uzelac, V.; Levaj, B. Polyphenol content of Marasca sour cherry ecotypes (Prunus cerasus Marasca) and its stability during freezing storage. Glas. Zaštite Bilja 2019, 42, 94-102.

25. Salomé-Abarca, L.F.; Mandrone, M.; Sanna, C.; Poli, F.; van der Hondel, C.A.; Klinkhamer, P.G.; Choi, Y.H. Metabolic variation in Cistus monspeliensis L. ecotypes correlated to their plant-fungal interactions. Phytochemistry 2020, 176, 112402.

26. Niczad, A.; Sharafzadeh, S.; Alizadeh, A.; Amiri, B.; Bazrafshan, F. Variability in Essential Oil Constituent, Phenolic Content, Antioxidant and Antimicrobial Activities of Different Ecotypes of Zataria multiflora Boiss. from Iran. J. Essent. Oil-Bear. Plants 2019, 22, 1435-1449. [CrossRef]

27. Chanioti, S.; Tzia, C. Optimization of ultrasound-assisted extraction of oil from olive pomace using response surface technology: Oil recovery, unsaponifiable matter, total phenol content and antioxidant activity. LWT Food Sci. Technol. 2017, 79, 178-189. [CrossRef]

28. Rocchetti, G.; Blasi, F.; Montesano, D.; Ghisoni, S.; Marcotullio, M.C.; Sabatini, S.; Lucini, L. Impact of conventional/nonconventional extraction methods on the untargeted phenolic profile of Moringa oleifera leaves. Food Res. Int. 2019, 115, 319-327. [CrossRef]

29. Odabaş, H.I.; Koca, I. Application of response surface methodology for optimizing the recovery of phenolic compounds from hazelnut skin using different extraction methods. Ind. Crop. Prod. 2016, 91, 114-124. [CrossRef]

30. Paz, J.E.W.; Contreras, C.R.; Munguía, A.R.; Aguilar, C.N.; Inungaray, M.L.C. Phenolic content and antibacterial activity of extracts of Hamelia patens obtained by different extraction methods. Braz. J. Microbiol. 2018, 49, 656-661. [CrossRef]

31. Celep, E.; Seven, M.; Akyüz, S.; İnan, Y.; Yesilada, E. Influence of extraction method on enzyme inhibition, phenolic profile and antioxidant capacity of Sideritis trojana Bornm. S. Afr. J. Bot. 2019, 121, 360-365. [CrossRef]

32. Sepahpour, S.; Selamat, J.; Abdul Manap, M.Y.; Khatib, A.; Abdull Razis, A.F. Comparative analysis of chemical composition, antioxidant activity and quantitative characterization of some phenolic compounds in selected herbs and spices in different solvent extraction systems. Molecules 2018, 23, 402. [CrossRef] [PubMed]

33. Lopes, A.P.; Petenuci, M.E.; Galuch, M.B.; Schneider, V.V.A.; Canesin, E.A.; Visentainer, J.V. Evaluation of effect of different solvent mixtures on the phenolic compound extraction and antioxidant capacity of bitter melon (Momordica charantia). Chem. Zvesti 2018, 72, 2945-2953. [CrossRef]

34. Lou, S.N.; Lai, Y.C.; Hsu, Y.S.; Ho, C.T. Phenolic content, antioxidant activity and effective compounds of kumquat extracted by different solvents. Food Chem. 2016, 197, 1-6. [CrossRef] [PubMed]

35. Saha, S.; Barua, B.; Sikdar, D. Phytochemical screening, phenolic content and antioxidant activity of wild date palm (Phoenix sylvestris Roxb.) fruit extracted with different solvents. Int. Food Res. J. 2017, 24, 2534-2542.

36. Verma, M.; Rai, G.K.; Kaur, D. Effect of extraction solvents on phenolic content and antioxidant activities of Indian gooseberry and guava. Int. Food Res. J. 2018, 25, 762-768.

37. Jonasson, S.; Bryant, J.P.; Chapin, F.S., III; Andersson, M. Plant phenols and nutrients in relation to variations in climate and rodent grazing. Am. Nat. 1986, 128, 394-408. [CrossRef]

38. Guedes, M.N.S.; Pio, R.; Maro, L.A.C.; Lage, F.F.; Abreu, C.M.P.D.; Saczk, A.A. Antioxidant activity and total phenol content of blackberries cultivated in a highland tropical climate. Acta Sci. Agron. 2017, 39, 43-48. [CrossRef]

39. Souhir, K.; Dorra, S.; Bettaib, R.I.; Mattew, S.; Neila, T.F.; Marie-Laure, F.; Sonia, M. Influence of climate variation on phenolic composition and antioxidant capacity of Medicago minima populations. Sci. Rep. 2020, 10, 1-15.

40. Sun, R.Z.; Cheng, G.; Li, Q.; He, Y.N.; Wang, Y.; Lan, Y.B.; Cui, X.D. Light-induced variation in phenolic compounds in Cabernet Sauvignon grapes (Vitis vinifera L.) involves extensive transcriptome reprogramming of biosynthetic enzymes, transcription factors, and phytohormonal regulators. Front. Plant Sci. 2017, 8, 547. [CrossRef]

41. Kumar, S.; Yadav, A.; Yadav, M.; Yadav, J.P. Effect of climate change on phytochemical diversity, total phenolic content and in vitro antioxidant activity of Aloe vera (L.) Burm. f. BMC Res. Notes 2017, 10, 60. [CrossRef] [PubMed]

42. Jaouadi, R.; Cardoso, S.M.; Silva, A.M.; Yahia, I.B.H.; Boussaid, M.; Zaouali, Y. Variation of phenolic constituents of Tunisian Thymus capitatus (L.) Hoff. et Link. populations. Biochem. Syst. Ecol. 2018, 77, 10-15. [CrossRef]

43. Petropoulos, S.A.; Fernandes, Â.; Barros, L.; Ferreira, I.C. A comparison of the phenolic profile and antioxidant activity of different Cichorium spinosum L. ecotypes. J. Sci. Food Agric. 2018, 98, 183-189. [CrossRef] [PubMed]

44. Nawaz, A.; Sarfraz, M.; Sarwar, M.; Farooq, M. Ecological management of agricultural pests through allelopathy. Co-Evol. Second. Metab. 2020, 543-574. [CrossRef]

45. Scognamiglio, M.; Esposito, A.; D'Abrosca, B.; Pacifico, S.; Fiumano, V.; Tsafantakis, N.; Fiorentino, A. Isolation, distribution and allelopathic effect of caffeic acid derivatives from Bellis perennis L. Biochem. Syst. Ecol. 2012, 43, 108-113. [CrossRef] 
46. Scavo, A.; Rial, C.; Molinillo, J.M.; Varela, R.M.; Mauromicale, G.; Macias, F.A. The extraction procedure improves the allelopathic activity of cardoon (Cynara cardunculus var. altilis) leaf allelochemicals. Ind. Crop. Prod. 2019, 128, 479-487. [CrossRef]

47. Esmaeili, H.; Karami, A.; Maggi, F. Essential oil composition, total phenolic and flavonoids contents, and antioxidant activity of Oliveria decumbens Vent. (Apiaceae) at different phenological stages. J. Clean. Prod. 2018, 198, 91-95. [CrossRef]

48. Haghighi, T.M.; Saharkhiz, M.J.; Naddaf, F. Ontogenetic variability of Vitex pseudo-negundo essential oil and its phytotoxic activity. Sci. Hortic. 2019, 257, 108735. [CrossRef]

49. Zolkeflee, N.K.Z.; Isamail, N.A.; Maulidiani, M.; Abdul Hamid, N.A.; Ramli, N.S.; Azlan, A.; Abas, F. Metabolite variations and antioxidant activity of Muntingia calabura leaves in response to different drying methods and ethanol ratios elucidated by NMR-based metabolomics. Phytochem. Anal. 2020. [CrossRef]

50. Sant'Anna, V.; Biondo, E.; Kolchinski, E.M.; da Silva, L.F.S.; Corrêa, A.P.F.; Bach, E.; Brandelli, A. Total polyphenols, antioxidant, antimicrobial and allelopathic activities of spend coffee ground aqueous extract. Waste Biomass Valorization 2017, 8, 439-442. [CrossRef]

51. Ribeiro, R.C.; de Carvalho, M.G.; de Moraes, M.D.L.; Rossiello, R.O.P.; de Oliveira, D.R.; de Amorim, R.M.Q.; Junior, E.B. Chemical screening of Urochloa humidicola: Methods for characterizing secondary metabolites and allelopathic activity on forage legumes. Am. J. Plant Sci. 2018, 9, 1260-1278. [CrossRef]

52. Pavliuchenko, N.; Grygorieva, O.; Klymenko, S. Allelochemicals from Castanea Sativa Mill.: Plant-Root Environment Interactions. Agrobiodivers. Improv. Nutr. Health Life Qual. 2019, 31-37. [CrossRef]

53. Chotsaeng, N.; Laosinwattana, C.; Charoenying, P. Herbicidal Activities of Some Allelochemicals and Their Synergistic Behaviors toward Amaranthus tricolor L. Molecules 2017, 22, 1841. [CrossRef] [PubMed]

54. Rawat, P.; Narkhede, S.S.; Rane, A.D.; Mhaiske, V.M.; Dalvi, V.V. Allelopathic effect of leaf leachates of solid bamboo Dendrocalamus stocksii (Munro.) on growth and yield of Eleusine coracana L.(Gaertn.). Indian J. 2017, 19, 79-82.

55. Wang, R.L.; Liu, S.W.; Xin, X.W.; Chen, S.; Peng, G.X.; Su, Y.J.; Song, Z.K. Phenolic acids contents and allelopathic potential of 10-cultivars of alfalfa and their bioactivity. Allelopath. J. 2017, 40, 63-70. [CrossRef]

56. Govêa, K.P.; Pereira, R.S.T.; de Assis, M.D.O.; Alves, P.I.; Brancaglion, G.A.; Toyota, A.E.; Trindade, L.D.O.R. Allelochemical activity of eugenol-derived coumarins on Lactuca sativa L. Plants 2020, 9, 533. [CrossRef]

57. Costas-Gil, A.; Dı'az-Tielas, C.; Reigosa, M.J.; Sa'nchez-Moreiras, A.M. Algicide activity of rosmarinic acid on Phaeodactylum tricornutum. J. Allel. Inter. 2015, 1, 39-47.

58. Ahuja, N.; Batish, D.R.; Singh, H.P.; Kohli, R.K. Herbicidal activity of eugenol towards some grassy and broad-leaved weeds. J. Pest Sci. 2015, 88, 209-218. [CrossRef]

59. Kalinova, J.; Triska, J.; Vrchotova, N. Occurence of eugenol, coniferyl alcohol and 3, 4, 5-trimethoxyphenol in common buckwheat (Fagopyrum esculentum Moench) and their biological activity. Acta Physiol. Plant. 2011, 33, 1679-1685. [CrossRef]

60. Hsueh, M.T.; Fan, C.; Chang, W.L. Allelopathic effects of Bidens pilosa L. var. radiata Sch. Bip. on the tuber sprouting and seedling growth of Cyperus rotundus L. Plants 2020, 9, 742.

61. Cao, J.; Dong, Z.; Zhao, H.; Duan, S.; Cao, X.; Liu, H.; Yang, Z. Allelopathic effect of rhubarb extracts on the growth of Microcystis aeruginosa. Water Sci. Technol. 2020. [CrossRef] [PubMed]

62. Karami, A.; Esmaeili, S.; Saharkhiz, M.J. Phytotoxic activity of Tecomella undulata (Sm.) Seem extracts on some ornamental plants. Biocatal. Agric. Biotechnol. 2017, 9, 177-182. [CrossRef]

63. Poulin, R.X.; Hogan, S.; Poulson-Ellestad, K.L.; Brown, E.; Fernández, F.M.; Kubanek, J. Karenia brevis allelopathy compromises the lipidome, membrane integrity, and photosynthesis of competitors. Sci. Rep. 2018, 8, 1-9. [CrossRef] [PubMed]

64. Dar, B.A.; Al-Rowaily, S.L.; Assaeed, A.M.; El-Bana, M.I.; Hegazy, A.K.; Malik, J.A. Allelopathic potential of Argemone ochroleuca from different habitats on seed germination of native species and cultivated crops. Pak. J. Bot. 2017, 49, 1841-1848.

65. Krenchinski, F.H.; Albrecht, L.P.; Albrecht, A.J.P.; Costa Zonetti, P.; Tessele, A.; Barroso, A.A.M.; Placido, H.F. Allelopathic potential of 'Cymbopogon citratus' over beggarticks ('Bidens' sp.) germination. Aust. J. Crop Sci. 2017, 11, 277. [CrossRef]

66. Kapoor, D.; Tiwari, A.; Sehgal, A.; Landi, M.; Brestic, M.; Sharma, A. Exploiting the allelopathic potential of aqueous leaf extracts of Artemisia absinthium and Psidium guajava against Parthenium hysterophorus, a widespread weed in India. Plants $2019,8,552$. [CrossRef]

67. Baličević, R.; Ravlić, M.; Kleflin, J.; Tomić, M. Allelopathic activity of plant species from Asteraceae and Polygonaceae family on lettuce. Herbologia 2016, 16, 23-30. [CrossRef]

68. Pratap Chandran, R.; Deepak, V.; Krishna, S.; Fathima, S.; Ameena, T.; Raj, J. Allelopathic Activity of Leaf Extracts of Mimosa pudica on Growth Parameters of Brassica juncea Seeds. Baoj Biotech. 2018, 4, 33.

69. Raoof, K.A.; Siddiqui, M.B. Allelopathic effect of aqueous extracts of different parts of Tinospora cordifolia (Willd.) Miers on some weed plants. J. Agric. Ext. Rural Dev. 2012, 4, 115-119.

70. Huang, W.; Reddy, G.V.; Shi, P.; Huang, J.; Hu, H.; Hu, T. Allelopathic effects of Cinnamomum septentrionale leaf litter on Eucalyptus grandis saplings. Glob. Ecol. Conserv. 2020, 21, e00872. [CrossRef]

71. Mahdavikia, F.; Saharkhiz, M.J. Secondary metabolites of peppermint change the morphophysiological and biochemical characteristics of tomato. Biocatal. Agric. Biotechnol. 2016, 7, 127-133. [CrossRef]

72. Biswas, K.; Das, A.P. Allelopathic effects of teak Tectona grandis Lf on germination and seedling growth of Plumbago zeylanica L. Pleione 2016, 10, 262-268. 
73. Ahmed, R.; Hoque, A.R.; Hossain, M.K. Allelopathic effects of leaf litters of Eucalyptus camaldulensis on some forest and agricultural crops. J. Res. 2008, 19, 19-24. [CrossRef]

74. Choudhari, S.W.; Chopde, T.; Mane, A.P.; Shambharkar, A.B.; Konde, N.M.; Wahurwagh, S.R.; Walke, R.D. Allelopathic effects of Acacia nilotica (L.) Leaf leachate with emphasis on Trigonella foenum graceum L. (fenugreek). J. Pharm. Phytochem. 2019, 8, 500-506.

75. Hussain, S.; Shehzad, M.; Siddiqui, M.; Awan, S. Allelopathic effect of Santa Maria (Parthenium hysterophrous) mulch on growth and yield of soybean (Glycine max). Planta Daninha 2016, 34, 631-638. [CrossRef]

76. Wang, C.; Wu, B.; Jiang, K. Allelopathic effects of Canada goldenrod leaf extracts on the seed germination and seedling growth of lettuce reinforced under salt stress. Ecotoxicology 2019, 28, 103-116. [CrossRef]

77. Khang, D.T.; Anh, L.H.; Ha, T.; Tuyen, P.T.; Quan, N.V.; Minh, L.T.; Trung, K.H. Allelopathic activity of dehulled rice and its allelochemicals on weed germination. Int. Lett. Nat. Sci. 2016, 58, 1-10. [CrossRef]

78. Nouri, H.; Talab, Z.A.; Tavassoli, A. Effect of weed allelopathic of sorghum (Sorghum halepense) on germination and seedling growth of wheat, Alvand cultivar. Ann. Biol. Res. 2012, 3, 1283-1293.

79. Al-Harbi, N.A. Allelopathic Effect of Leaf Extract of Two Wild Plants on Seed Germination, Shoot and Root Length of Two Weed Species; Portulaca Oleracea and Chenopodium Murale. Biosci. Biotechnol. Res. Asia 2018, 15, 929-935. [CrossRef]

80. Delinac, A. Assessment of allelopathic effect of St. John's wort (Hypericum perforatum L.) on lettuce. Ph.D. Thesis, Poljoprivredni fakultet u Osijeku, Sveučilište Josipa Jurja Strossmayera u Osijeku, Osijek, Croatia, 2017.

81. Isik, D.; Mennan, H.; Cam, M.; Tursun, N.; Arslan, M. Allelopathic potential of some essential oil bearing plant extracts on Common Lambsquarters (Chenopodium album L.). Rev. Chim. 2016, 67, 455-459.

82. Sadeghi, H.; Bazdar, M. Effects of Prangos ferulacea aqueous and hydroalcoholic extracts obtained from different organs on the regeneration of Trifolium resupinatum. Acta Physiol. Plant. 2018, 40, 50. [CrossRef]

83. Alqarawi, A.A.; Hashem, A.; Kumar, A.; Al-Arjani, A.B.F.; Abd_Allah, E.F.; Dar, B.A.; Egamberdieva, D. Allelopathic effects of the aqueous extract of Rhazya stricta on growth and metabolism of Salsola villosa. Plant Biosyst. 2018, 152, 1263-1273. [CrossRef]

84. Asrat, G.; Seid, A. Allelopathic effect of meskit (Prosopis juliflora (Sw.) DC) aqueous extracts on tropical crops tested under laboratory conditions. Momona Ethiop. J. Sci. 2017, 9, 32-42. [CrossRef]

85. Mushtaq, W.; Ain, Q.; Siddiqui, M.B.; Hakeem, K.R. Cytotoxic allelochemicals induce ultrastructural modifications in Cassia tora L. and mitotic changes in Allium cepa L.: A weed versus weed allelopathy approach. Protoplasma 2019, 256, 857-871. [CrossRef]

86. Franco, D.M.; Saldanha, L.L.; Silva, E.M.; Nogueira, F.T.S.; Dokkedal, A.L.; Santos, C.D.; Almeida, L.F. Effects of leaf extracts of Myrcia guianensis (Aubl.) DC.: On growth and gene expression during root development of Sorghum bicolor (L.) Moench. Allelopath. J. 2015, 35, 237-248.

87. Yang, Y.; Wu, F.; Zhou, X. Protein expression in accessions of Chinese onion with different allelopathic potentials under monocropping and intercropping systems. Acta Physiol. Plant. 2013, 35, 2241-2250. [CrossRef]

88. Mushtaq, W.; Siddiqui, M.B. Allelopathy in Solanaceae plants. J. Plant Prot. Res. 2018, 58, 1.

89. Stanišić, M.; Ćosić, T.; Savić, J.; Krstić-Milošević, D.; Mišić, D.; Smigocki, A.; Banjac, N. Hairy root culture as a valuable tool for allelopathic studies in apple. Tree Physiol. 2019, 39, 888-905. [CrossRef]

90. Ming, Y.; Zhu, Z.J.; Li, J.; Hu, G.X.; Fan, X.M.; Yuan, D.Y. Allelopathic Effects of Castanea henryi Aqueous Extracts on the Growth and Physiology of Brassica pekinensis and Zea mays. Chem. Biodivers. 2020, 17, e2000135. [CrossRef] [PubMed]

91. Ben Gharbia, H.; Kéfi-Daly Yahia, O.; Cecchi, P.; Masseret, E.; Amzil, Z.; Herve, F.; Zmerli Triki, H. New insights on the species-specific allelopathic interactions between macrophytes and marine HAB dinoflagellates. PLoS ONE 2017, 12, e0187963. [CrossRef]

92. Da Silva, E.R.; Overbeck, G.E.; Soares, G.L.G. Something old, something new in allelopathy review: What grassland ecosystems tell us. Chemoecology 2017, 27, 217-231. [CrossRef]

93. Abdelmigid, H.M.; Morsi, M.M. Cytotoxic and molecular impacts of allelopathic effects of leaf residues of Eucalyptus globulus on soybean (Glycine max). J. Genet. Eng. Biotechnol. 2017, 15, 297-302. [CrossRef] [PubMed]

94. Shah, S.H.; Khan, E.A.; Shah, H.; Ahmad, N.; Khan, J.; Sadozai, G.U. Allelopathic sorghum water extract helps to improve yield of sunflower (Helianthus annuus L.). Pak. J. Bot. 2016, 48, 1197-1202.

95. Naeem, M.; Cheema, Z.A.; Ihsan, M.Z.; Hussain, Y.; Mazari, A.; Abbas, H.T. Allelopathic effects of different plant water extracts on yield and weeds of wheat. Planta Daninha 2018, 36. [CrossRef]

96. Kamran, M.; Cheema, Z.A.; Farooq, M.; Hassan, A.U. Influence of foliage applied allelopathic water extracts on the grain yield, quality and economic returns of hybrid maize. Int. J. Agric. Biol. 2016, 18, 577-583. [CrossRef]

97. Xiaobang, P.E.N.G. Allelopathic effects of water extracts of maize leaf on three chinese herbal medicinal plants. Not. Bot. Horti Agrobot. Cluj Napoca 2019, 47, 194-200.

98. Rice-Evans, C.A.; Miller, N.J.; Paganga, G. Antioxidant properties of phenolic compounds. Trends Plant Sci. 1997, 2, 152-159. [CrossRef]

99. Kamran, M.; Cheema, Z.A.; Farooq, M.; Ali, Q.; Anjum, M.Z.; Raza, A. Allelopathic Influence of Sorghum Aqueous Extract on Growth, Physiology and Photosynthetic Activity of Maize (Zea mays L.) Seedling. Philipp. Agric. Sci. 2019, $102,33-41$.

100. Sekutowski, T.; Domaradzki, K.; Jezierska-Domaradzka, A.; Matkowski, A.; Stochmal, A. Ocena potencjału allelopatycznego Solidago gigantea Aiton w odniesieniu do suchej masy Echinochloa crus-galli (L.) Beauv. oraz Amaranthus retroflexus L. J. Cent. Eur. Agric. 2019, 20, 402-414. [CrossRef] 
101. D'Abrosca, B.; DellaGreca, M.; Fiorentino, A.; Monaco, P.; Natale, A.; Oriano, P.; Zarrelli, A. Structural characterization of phytotoxic terpenoids from Cestrum parqui. Phytochemistry 2005, 66, 2681-2688. [CrossRef]

102. Ravlić, M.; Baličević, R.; Visković, M.; Smolčić, I. Response of weed species on allelopathic potential of Aloe vera (L.) Burm. f. Herbologia 2017, 16, 49-55.

103. Marinov-Serafimov, P.; Dimitrova, T.; Golubinova, I. Allelopathy: Element of an overall strategy for weed control. Acta Agric. Serb. 2013, 18, 23-37.

104. Kerdar, T.; Moradkhani, S.; Dastan, D. Phytochemical and biological studies of Scrophularia striata from Ilam. Jundishapur J. Nat. Pharm. Prod. 2018, 13. [CrossRef]

105. Macías, F.A.; Castellano, D.; Molinillo, J.M. Search for a standard phytotoxic bioassay for allelochemicals. Selection of standard target species. J. Agric. Food Chem. 2000, 48, 2512-2521. [CrossRef] [PubMed]

106. Weber, S.S.; Kaminski, K.P.; Perret, J.L.; Leroy, P.; Mazurov, A.; Peitsch, M.C.; Hoeng, J. Antiparasitic properties of leaf extracts derived from selected Nicotiana species and Nicotiana tabacum varieties. Food Chem. Toxicol. 2019, 132, 110660. [CrossRef] [PubMed]

107. Mouradi, M.; Bouizgaren, A.; Farissi, M.; Makoudi, B.; Kabbadj, A.; Very, A.A.; Ghoulam, C. Osmopriming improves seeds germination, growth, antioxidant responses and membrane stability during early stage of Moroccan alfalfa populations under water deficit. Chil. J. Agric. Res. 2016, 76, 265-272. [CrossRef] 